\title{
Separation of the minor actinides
} americium(III) and curium(III) by hydrophobic and hydrophilic BTPhen ligands: exploiting differences in their rates of extraction and effective separations at equilibrium

Article

Accepted Version

Lewis, F. W., Harwood, L. M., Hudson, M. J., Afsar, A., Laventine, D. M., John, J., Stastna, K. and Distler, P. (2018) Separation of the minor actinides americium(III) and curium(III) by hydrophobic and hydrophilic BTPhen ligands: exploiting differences in their rates of extraction and effective separations at equilibrium. Solvent Extraction and Ion Exchange, 36 (2). pp. 115-135. ISSN 0736-6299 doi: https://doi.org/10.1080/07366299.2018.1429358 Available at https://centaur.reading.ac.uk/73211/

It is advisable to refer to the publisher's version if you intend to cite from the work. See Guidance on citing.

To link to this article DOI: http://dx.doi.org/10.1080/07366299.2018.1429358

Publisher: Taylor \& Francis 
All outputs in CentAUR are protected by Intellectual Property Rights law, including copyright law. Copyright and IPR is retained by the creators or other copyright holders. Terms and conditions for use of this material are defined in the End User Agreement.

\section{www.reading.ac.uk/centaur}

\section{CentAUR}

Central Archive at the University of Reading

Reading's research outputs online 


\section{Separation of the Minor Actinides Americium(III)}

\section{and Curium(III) Using Differences in their Rates of}

\section{Extraction by Bis-(1,2,4-triazin-3-yl)phenanthrolines}

Frank W. Lewis, ${ }^{* \dagger}$ Laurence M. Harwood, ${ }^{\ddagger}$ Michael J. Hudson, ${ }^{+\|}$Ashfaq Afsar, Dominic M. Laventine, ${ }^{\ddagger}$ Kamila Štastná, ${ }^{\S}$ Jan John ${ }^{\S}$ and Petr Distler ${ }^{\S}$

Department of Applied Sciences, Faculty of Health and Life Sciences, Northumbria University, Newcastle upon Tyne NE1 8ST, UK, Department of Chemistry, University of Reading, Whiteknights, Reading RG6 6AD, UK and Department of Nuclear Chemistry, Czech Technical University in Prague, Břehová 7, 11519 Prague 1, Czech Republic.

\section{E-mail: frank.lewis@northumbria.ac.uk}

\section{RECEIVED DATE}

Separation of Am(III) and Cm(III)

$\dagger$ Northumbria University, $\star$ University of Reading, § Department of Nuclear Chemistry, ॥ Deceased on $26^{\text {th }}$ January 2016.

ABSTRACT. The complexation and extraction of the adjacent minor actinides Am(III) and Cm(III) by both hydrophobic and hydrophilic pre-organized 2,9-bis(1,2,4-triazin-3-yl)-1,10phenanthroline (BTPhen) ligands has been studied in detail. It has been shown that Am(III) is 
extracted more rapidly than $\mathrm{Cm}$ (III) by the hydrophobic $\mathrm{CyMe}_{4}-\mathrm{BTPhen}$ ligand into different organic diluents under non-equilibrium extraction conditions, leading to separation factors for Am over $\mathrm{Cm}\left(\mathrm{SF}_{\mathrm{Am} / \mathrm{Cm}}\right)$ as high as 7.9. Furthermore, the separation of $\mathrm{Am}(\mathrm{III})$ from $\mathrm{Cm}(\mathrm{III})$ can be tuned through careful choice of the extraction conditions (organic diluent, contact time, mixing speed, ligand concentration). This 'kinetic' effect is attributed to the higher presumed kinetic lability of the Am(III) aqua complex towards ligand substitution. A dependence of the $\mathrm{Am}(\mathrm{III}) / \mathrm{Cm}(\mathrm{III})$ selectivity on the structure of the alkyl groups attached to the triazine rings is also observed, and BTPhens bearing linear alkyl groups are less able to separate Am(III) from $\mathrm{Cm}$ (III) than $\mathrm{CyMe}_{4}-\mathrm{BTPhen}$. Under equilibrium extraction conditions, hydrophilic tetrasulfonated BTPhen ligands complex selectively Am(III) over $\mathrm{Cm}(\mathrm{III})$ and prevent the extraction of $\mathrm{Am}(\mathrm{III})$ from nitric acid by the hydrophobic $O$-donor ligand $N, N, N^{\prime}, N^{\prime}$ tetraoctyldiglycolamide (TODGA), giving separation factors for $\mathrm{Cm}(\mathrm{III})$ over $\mathrm{Am}(\mathrm{III})\left(\mathrm{SF}_{\mathrm{Cm} / \mathrm{Am}}\right)$ of up to 4.6. These results further underline the utility of the BTPhen ligands for the extremely challenging separation of the chemically similar minor actinides Am(III) and Cm(III) in future processes to close the nuclear fuel cycle.

Keywords: Americium, 1,2,4-Triazine, Curium, Separation, Kinetic Effect, BTPhen Ligand.

\section{Introduction}

Spent nuclear fuel from power plants is comprised of uranium (ca. $94 \%$ ), plutonium (ca. $1 \%$ ), fission and corrosion products, including the lanthanides (ca. $5 \%$ ), and the trans-uranic minor actinides americium, curium and neptunium (ca. $0.1 \%$ ). The PUREX process has been in industrial operation since the 1950s and removes the bulk of the uranium and plutonium from spent fuel. ${ }^{1}$ However, the minor actinides americium, curium and neptunium remain in the post- 
PUREX raffinate and they account for much of its long-lived radiotoxicity ( $c a .10,000$ years) and heat load. Removing these elements is therefore considered a major objective in future strategies for the reprocessing of spent nuclear fuel. ${ }^{2}$ As well as reducing the volume of waste that needs to be vitrified and stored in deep geological repositories, removal of the minor actinides would also greatly reduce the heat load and radiotoxicity of the remaining waste (to $c a .300$ years to decay to the levels of natural uranium). A key strategy for spent nuclear fuel reprocessing is the 'Partitioning and Transmutation' (P\&T) strategy. ${ }^{3}$ In this strategy, the minor actinides are first separated from the lanthanides and other fission products, and then transmuted to shorter-lived radionuclides or stable non-radioactive elements by high energy neutron bombardment in advanced nuclear reactors or dedicated (accelerator-driven) transmuters. The minor actinides must first be separated from the lanthanides due to the high neutron affinity of the latter, which would preferentially absorb the neutrons, interfere with the chain-reaction in the reactor/transmuter, suppress the transmutation of the minor actinides, and generate additional radioactive waste.

In recent years, many soft $N$-heterocycles have been studied to carry out the challenging separation of the trivalent actinides from the chemically similar trivalent lanthanides in a solvent extraction process. ${ }^{4}$ Despite the similar chemical properties of the trivalent actinides and lanthanides, $N$-donor ligands containing lateral 1,2,4-triazine rings (bis-(1,2,4)-triazine ligands) are able to perform this difficult separation. 2,6-Bis(1,2,4-triazin-3-yl)pyridines (BTPs), 6,6'bis(1,2,4-triazin-3-yl)-2,2'-bipyridines $\quad$ (BTBPs) and 2,9-bis(1,2,4-triazin-3-yl)-1,10phenanthrolines (BTPhens) have emerged as the ligands of choice for this separation. The hydrophobic bis-(1,2,4)-triazine ligands CyMe 4 -BTP 1, CyMe-BTBP 2 and CyMe4-BTPhen 3 (Figure 1) have become the most promising ligands for this separation to date, and are all able to 
separate the minor actinides $\mathrm{Am}(\mathrm{III})$ and $\mathrm{Cm}$ (III) from the lanthanides via selective extraction of the actinides from aqueous nitric acid into an organic phase with very high selectivities. $\mathrm{CyMe}_{4}-$ BTBP 2 has been applied successfully in a number of post-PUREX laboratory-scale selective actinide extraction (or 'SANEX') processes and is thus the current reference ligand for selective actinide extraction in Europe. ${ }^{5}$ More recently, pre-organized BTPhen ligands such as $\mathrm{CyMe}_{4}-$ BTPhen 3 have shown much improved extraction kinetics compared to CyMe 4 -BTBP $2 .{ }^{6}$

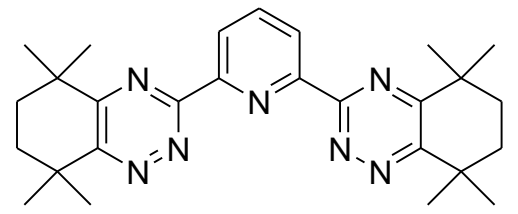

1

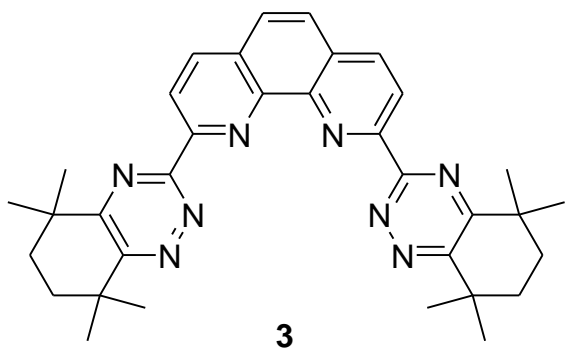

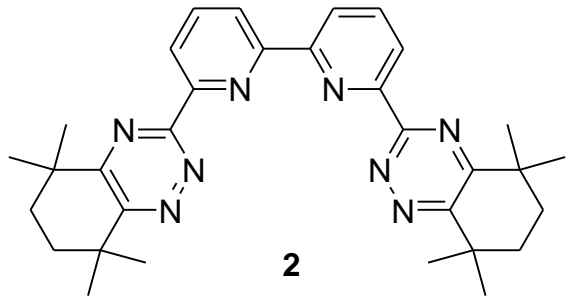

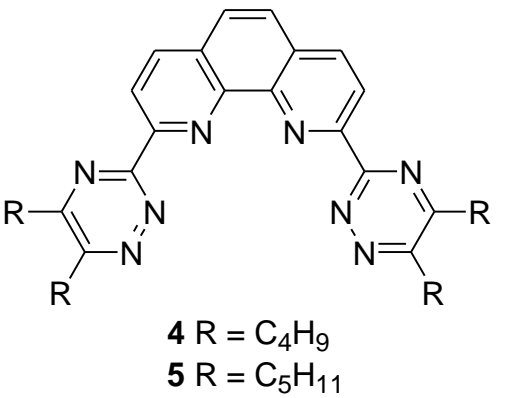

Figure 1. Hydrophobic bis-1,2,4-triazine ligands 1-5 for selective actinide extraction.

An alternative approach to the separation of the minor actinides from the lanthanides via selective actinide extraction into an organic phase has been proposed. This approach is based on the 'TALSPEAK' process, which was developed at Oak Ridge National Laboratory in the United States in the 1960s. ${ }^{7}$ In this process, the minor actinides and lanthanides are first co-extracted into an organic phase using a non-selective oxygen donor ligand, and the minor actinides are then selectively back-extracted into an aqueous phase using an actinide-selective hydrophilic ligand. In a recent improvement to this process, hydrophilic tetrasulfonated bis-(1,2,4)-triazine 
ligands such as BTP 6, BTBPs $\mathbf{7}$ and $\mathbf{8}$, and BTPhens $\mathbf{9}$ and $\mathbf{1 0}$ (Figure 2) were developed as actinide-selective aqueous complexing agents. ${ }^{8}$ These ligands are able to complex the trivalent minor actinides in nitric acid solutions and prevent their extraction by the non-selective hydrophobic ligand $N, N, N^{\prime}, N^{\prime}$-tetraoctyldiglycolamide (TODGA), resulting in highly efficient separations of Am(III) and Cm(III) from the lanthanides. Recently, tetrasulfonated BTP 6 was successfully employed in a new European laboratory-scale minor actinide separation process based on the TALSPEAK concept. ${ }^{9}$<smiles>CS(=O)(=O)c1cccc(-c2nnc(-c3cccc(-c4nnc(-c5cccc(S(N)(=O)=O)c5)c(-c5cccc(S(N)(=O)=O)c5)n4)n3)nc2-c2cccc(S(C)(=O)=O)c2)c1</smiles>

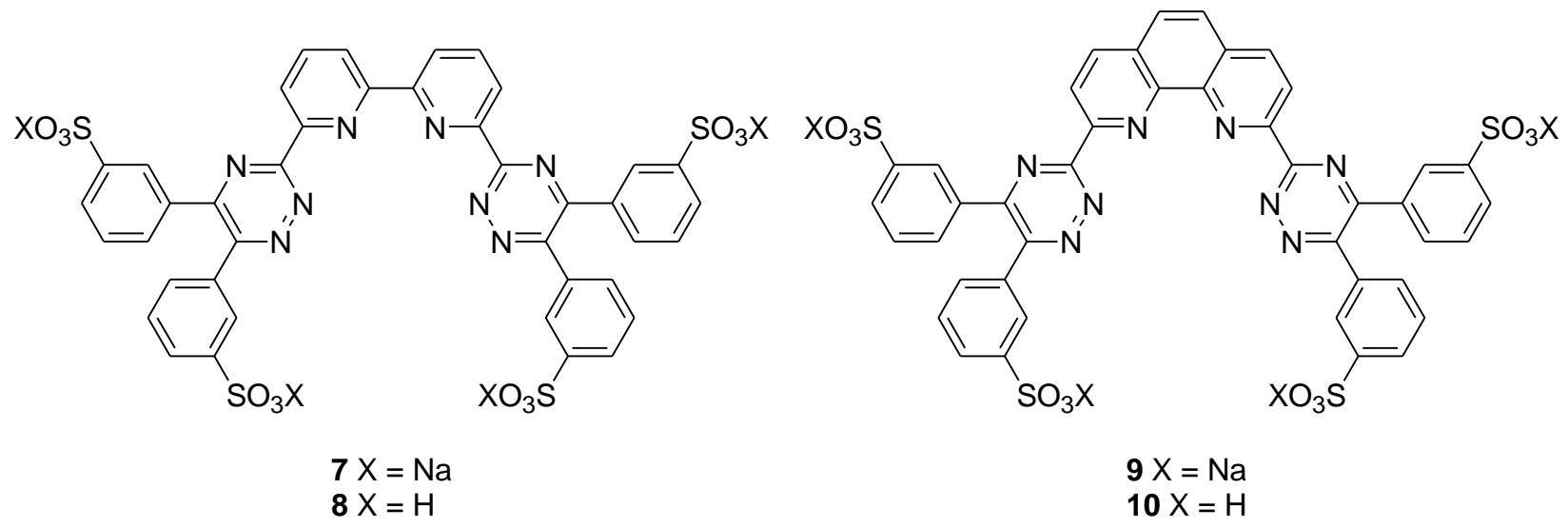

Figure 2. Hydrophilic tetrasulfonated bis-1,2,4-triazine ligands 6-10 for selective actinide aqueous complexation.

After the separation of the trivalent minor actinides from the trivalent lanthanides, one further option in the P\&T strategy is to separate $\mathrm{Am}(\mathrm{III})$ from $\mathrm{Cm}(\mathrm{III})$. This separation is desirable since Am(III) makes a greater contribution to the long term radiotoxicity and heat load than does 
$\mathrm{Cm}(\mathrm{III})$, and it is easier to fabricate into fuel and more easily transmuted in a reactor. ${ }^{10}$ For these reasons, it is desirable to develop a process that separates $\mathrm{Am}$ (III) from $\mathrm{Cm}$ (III) by selective extraction of only Am(III) into an organic phase. However, the separation of Am(III) from $\mathrm{Cm}$ (III) is even more challenging than the separation of $\mathrm{Am}(\mathrm{III}) / \mathrm{Cm}(\mathrm{III})$ from the trivalent lanthanides, as americium and curium are neighboring elements in the actinide series. Thus the very similar chemistries of these adjacent elements render this separation one of the most challenging in the partitioning and transmutation approach. ${ }^{11}$ Am(III) has the electronic configuration $[\mathrm{Rn}] 5 \mathrm{f}^{6}$ whereas $\mathrm{Cm}(\mathrm{III})$ has the configuration $[\mathrm{Rn}] 5 \mathrm{f}^{7}$. Both ions have very similar ionic radii for their 9-coordinate aqua ions (1.122 $\AA$ for Am(III) versus $1.105 \AA$ for $\mathrm{Cm}(\mathrm{III})){ }^{12}$ Both elements exist as trivalent ions in aqueous solution and the metal-ligand bonding in both ions is essentially ionic, but with some covalent contribution to the bonding. The chemical properties of both ions are thus almost identical.

Not surprisingly, very few methods exist for separating Am(III) from $\mathrm{Cm}$ (III). The selective extraction of Am(III) by a mixture of a dithiophosphinic acid and a phosphate has been proposed and demonstrated, giving selectivities for $\mathrm{Am}(\mathrm{III})$ over $\mathrm{Cm}(\mathrm{III})$ of $\sim 8 .{ }^{13}$ However, the dithiophosphinic acid extractants are susceptible to hydrolysis and oxidation at low $\mathrm{pH}$. Furthermore, the extractants contain elements other than $\mathrm{C}, \mathrm{H}, \mathrm{O}$ and $\mathrm{N}$, meaning that incineration leads to corrosive products at the end of the process. Selective extraction of Am(III) from PUREX raffinate with a combination of $O$-donor diamide ligands has also been demonstrated. ${ }^{14}$ Unfortunately, the process required a large number of stages to separate Am(III) from $\mathrm{Cm}(\mathrm{III})$ fully, due to the relatively low selectivity of the system [2.5 times more selective for Am(III)]. Another approach involves selective oxidation of Am(III) to higher oxidation states which have different coordination chemistries and thus different extraction properties to 
$\mathrm{Cm}(\mathrm{III}) .{ }^{15}$ In one such approach, Am(III) was selectively oxidized to $\mathrm{Am}(\mathrm{V})$ prior to its separation from $\mathrm{Cm}(\mathrm{III})$ by ion exchange chromatography. ${ }^{16}$ However, it is difficult to implement this strategy on the scale required for a continuous solvent extraction process. Similarly, Am(III) has been selectively oxidized to Am(VI) prior to its separation from $\mathrm{Cm}$ (III) by liquid-liquid extraction. ${ }^{17}$ Although the feasibility of this approach was demonstrated at laboratory-scale, the process uses sodium bismuthate as oxidant which is only sparingly soluble in nitric acid; necessitating the need for a filtration step prior to extraction of Am(VI). Recently, the selective complexation of Am(III) over Cm(III) by a crown-ether, based on the slightly larger ionic radius of Am(III) has been suggested, and a selectivity for Am(III) over Cm(III) of 4.1 (based on stability constants) has been reported. ${ }^{18}$ We have previously reported that subtle electronic modulation of the BTPhen ligands with substituents can enhance the inherent selectivity of this ligand system for Am(III) over Cm(III), giving separation factors for Am(III) over $\mathrm{Cm}(\mathrm{III})\left(\mathrm{SF}_{\mathrm{Am} / \mathrm{Cm}}\right)$ as high as $7 .{ }^{19} \mathrm{We}$ now report herein a full account of our studies on the separation of $\mathrm{Am}$ (III) from $\mathrm{Cm}$ (III) using both hydrophobic and hydrophilic bis-(1,2,4)-triazine ligands, and we demonstrate that feasible separations of Am(III) from Cm(III) can be achieved under different sets of conditions using both families of ligands, partuclularly when not working at equilibrium. We also discuss the likely underlying fundamental reasons for the selectivities that we observe.

\section{Results and Discussion}

Separation of Am(III) from Cm(III) by hydrophobic ligands in 1-octanol. In our previous report on the separation of $\mathrm{Am}(\mathrm{III})$ from $\mathrm{Eu}(\mathrm{III})$ by $\mathrm{CyMe}_{4}$-BTPhen 3 using 1-octanol as the diluent, we studied the co-extraction of $\mathrm{Am}(\mathrm{III})$ and $\mathrm{Cm}(\mathrm{III})$ under conditions that were designed to lower the $D$ values of both metals to allow for easier back-extraction in the stripping step. ${ }^{\mathrm{XX}}$ 
NEED A REFWe thus decided to vary the conditions systematically (nitric acid concentration, ligand concentration, diluent composition) in order to obtain a broader picture of the ability of CyMe 4 -BTPhen 3 to separate Am(III) from $\mathrm{Cm}(\mathrm{III})$ under equilibrium conditions using 1octanol as the diluent. The extraction of $\mathrm{Am}(\mathrm{III})$ and $\mathrm{Cm}(\mathrm{III})$ from nitric acid solutions into 1octanol by $\mathrm{CyMe}_{4}-\mathrm{BTPhen} 3$ is presented in Figure 3. A lower ligand concentration was used here $(1 \mathrm{mM})$ than that previously reported ${ }^{\mathrm{XX}}$ so that the $D$ values measured would be lower and thus more precise.

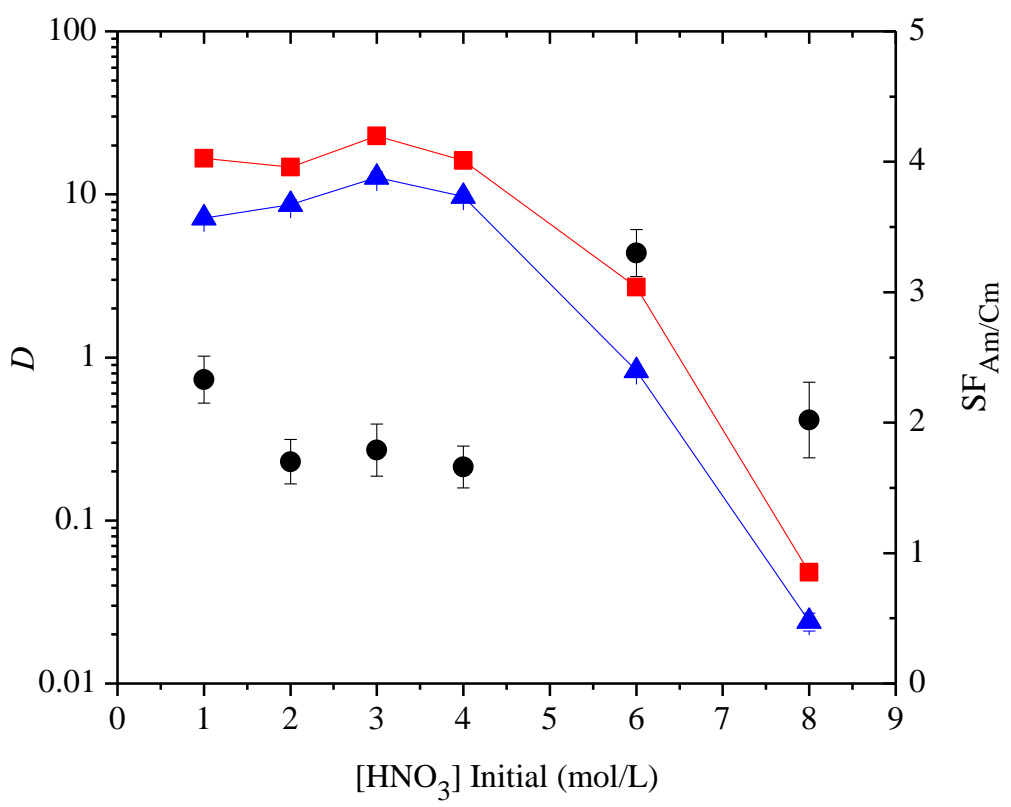

Figure 3. Selective extraction of Am(III) over Cm(III) from nitric acid by solutions of $\mathrm{CyMe}_{4}-$ BTPhen 3 in 1-octanol $(0.001 \mathrm{M})$ as a function of the initial nitric acid concentration of the aqueous phase $\left(\boldsymbol{\square}=D_{\mathrm{Am}}, \boldsymbol{\Delta}=D_{\mathrm{Cm}}, \bullet=\mathrm{SF}_{\mathrm{Am} / \mathrm{Cm}}\right.$, contact time $=2$ hours at $\left.1800 \mathrm{rpm}, \mathrm{T}=22^{\circ} \mathrm{C}\right)$.

As shown, the $D$ values for $\mathrm{Am}(\mathrm{III})$ are slightly larger than those for $\mathrm{Cm}(\mathrm{III})$, but there is no significant selectivity for Am(III) over Cm(III) under these conditions. The maximum separation factor for $\mathrm{Am}(\mathrm{III})$ over $\mathrm{Cm}(\mathrm{III})\left(\mathrm{SF}_{\mathrm{Am} / \mathrm{Cm}}\right)$ is found to be 3.3 in $6 \mathrm{M} \mathrm{HNO}_{3}$. However, even with 
this modest selectivity, a feasible separation of $\mathrm{Am}(\mathrm{III})$ and $\mathrm{Cm}$ (III) could be achieved by liquidliquid extraction under these conditions as $D_{\mathrm{Am}}>1$ and $D_{\mathrm{Cm}}<1 \mathrm{HMMMM}-$ ONLY JUST PROBABLY STRESS THE TOLERANCE IS TOO CLOSE - MAKES THE KINETIC RESULTS LOOK BETTER. We also examined the separation of Am(III) from Eu(III) under these conditions and found that the maximum separation factor for Am(III) over Eu(III) was also found at this acidity $\left(\mathrm{SF}_{\mathrm{Am} / \mathrm{Eu}}=338\right.$ in $6 \mathrm{M} \mathrm{HNO}_{3}$, see Supporting Information). We also studied the extraction of $\mathrm{Am}(\mathrm{III})$ and $\mathrm{Cm}(\mathrm{III})$ from $1 \mathrm{M} \mathrm{HNO}_{3}$ by $\mathrm{CyMe}_{4}-\mathrm{BTPhen} 3$ as a function of contact time, and found that equilibrium was achieved within 2 hours of phase mixing using a Heidolph Multi Reax shaker at 1,800 rpm. The variation in $\mathrm{SF}_{\mathrm{Am} / \mathrm{Cm}}$ with contact time is shown in Figure 4.

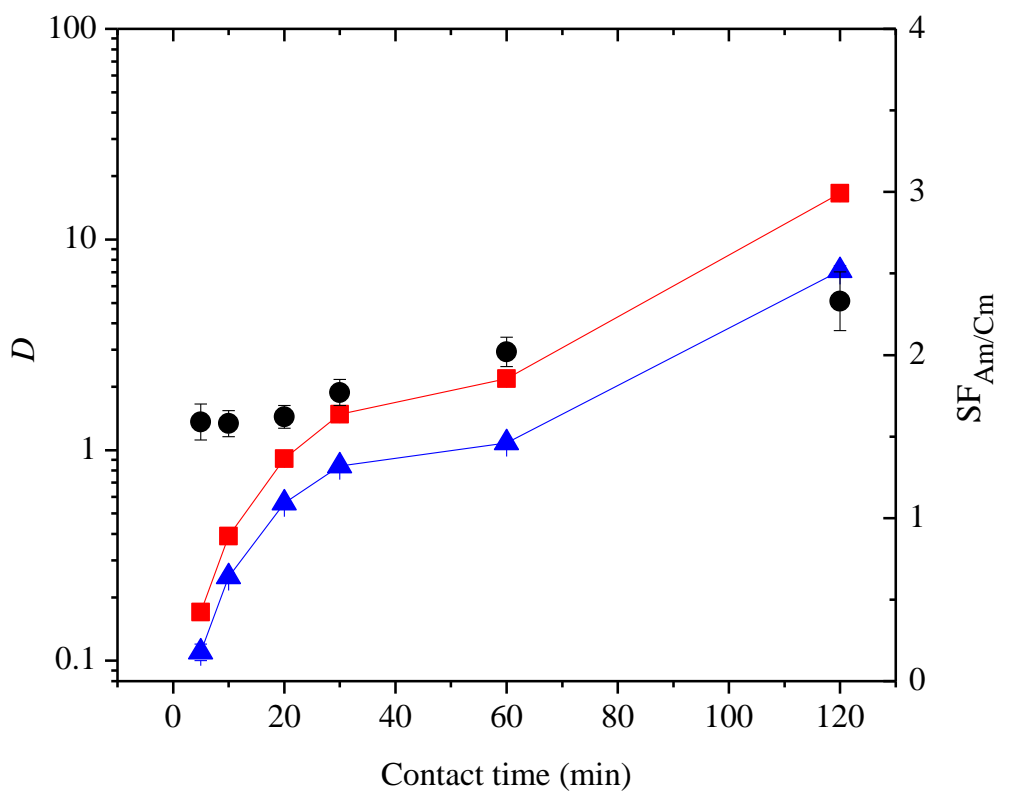

Figure 4. Selective extraction of $\mathrm{Am}$ (III) over $\mathrm{Cm}$ (III) from $1 \mathrm{M}$ nitric acid by solutions of $\mathrm{CyMe}_{4}-\mathrm{BTPhen} \mathbf{3}$ in 1-octanol $(0.001 \mathrm{M})$ as a function of contact time $\left(\mathbf{-}=D_{\mathrm{Am}}, \boldsymbol{\Delta}=D_{\mathrm{Cm}}, \bullet=\right.$ $\mathrm{SF}_{\mathrm{Am} / \mathrm{Cm}}$, mixing at $\left.1800 \mathrm{rpm}, \mathrm{T}=22^{\circ} \mathrm{C}\right)$. 
In our previous work on $\mathrm{CyMe}_{4}-\mathrm{BTPhen} \mathrm{3}$, we studied 1-octanol/toluene mixtures as the organic phase and found a significant selectivity for $\mathrm{Am}$ (III) over $\mathrm{Cm}$ (III) under certain conditions $\left(\mathrm{SF}_{\mathrm{Am} / \mathrm{Cm}}=4.0\right.$. Organic phase: $0.01 \mathrm{M}$ CyMe $4-\mathrm{BTPhen} 3$ in 1-octanol/toluene (40:60); Aqueous phase: $\left.4.0 \mathrm{M} \mathrm{HNO}_{3}\right) .{ }^{\mathrm{XX}}$ We therefore decided to probe the separation of $\mathrm{Am}(\mathrm{III})$ from $\mathrm{Cm}(\mathrm{III})$ in this solvent system more deeply in order to see if this selectivity could be replicated. The extraction of $\mathrm{Am}$ (III) and $\mathrm{Cm}$ (III) into 1-octanol/toluene (40:60) as a function of $\left[\mathrm{HNO}_{3}\right]$ is shown in Figure 5. Although these conditions are not identical to those reported in our previous work (longer contact time, slower orbital shaker), a significantly high selectivity for $\mathrm{Am}(\mathrm{III})$ over $\mathrm{Cm}$ (III) was again observed; this time in the extraction from $1 \mathrm{M} \mathrm{HNO}_{3}\left(\mathrm{SF}_{\mathrm{Am} / \mathrm{Cm}}=\right.$ 6.5). The selectivity for $\mathrm{Am}(\mathrm{III})$ over $\mathrm{Cm}(\mathrm{III})$ found at $4 \mathrm{M} \mathrm{HNO}_{3}\left(\mathrm{SF}_{\mathrm{Am} / \mathrm{Cm}}=3.1\right)$ is slightly lower than that reported previously. ${ }^{\mathrm{XX}}$ The selectivity observed at $1 \mathrm{M} \mathrm{HNO}_{3}$ would be more than sufficient for a feasible separation of $\mathrm{Am}(\mathrm{III})$ from $\mathrm{Cm}(\mathrm{III})$ provided that $D_{\mathrm{Am}}>1$ and $D_{\mathrm{Cm}}$ $<1$. We also briefly looked at the separation of $\mathrm{Am}$ (III) from $\mathrm{Eu(III)}$ under these conditions and found that an efficient separation of $\mathrm{Am}$ (III) from $\mathrm{Eu}$ (III) could be achieved in $1 \mathrm{M} \mathrm{HNO}_{3}$ (see Supporting Information). Unfortunately, when the concentration of $\mathrm{CyMe}_{4}-\mathrm{BTPhen} 3$ was lowered to $0.001 \mathrm{M}$ (ie: to bring the $D$ values down), the selectivity for Am(III) over Cm(III) at 1 $\mathrm{M} \mathrm{HNO}_{3}$ decreased to 2.7 (see Supporting Information). 


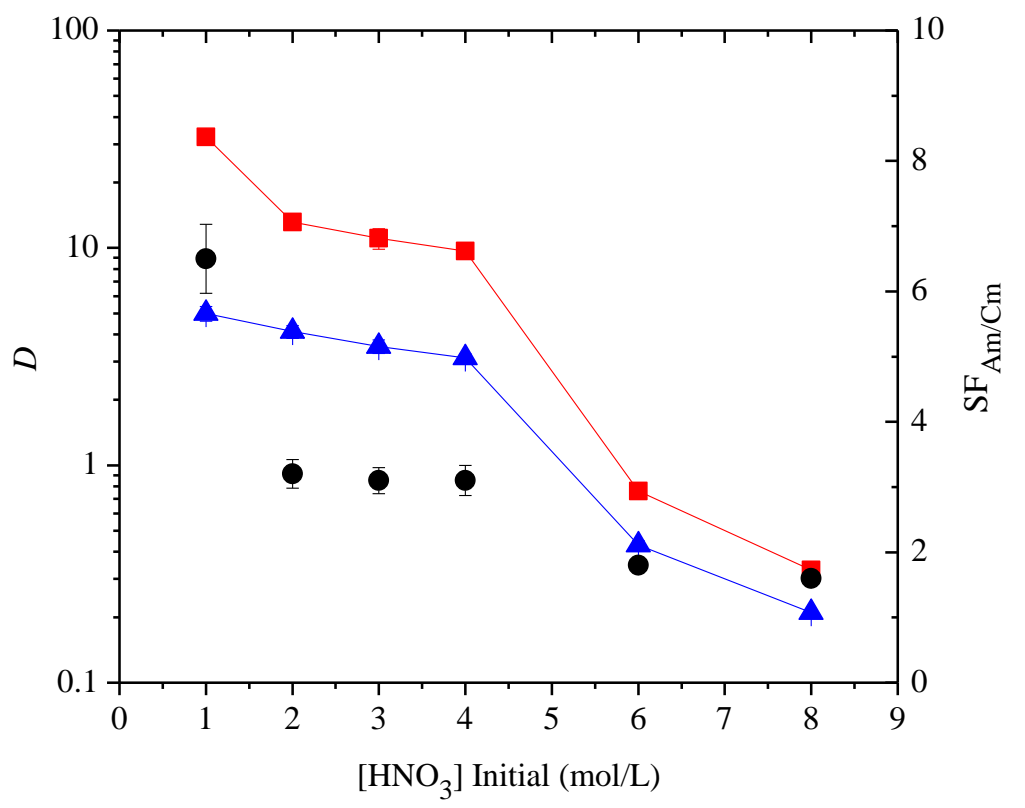

Figure 5. Selective extraction of $\mathrm{Am}(\mathrm{III})$ over $\mathrm{Cm}$ (III) from nitric acid by $0.01 \mathrm{M}$ solutions of $\mathrm{CyMe}_{4}$-BTPhen 3 in 1-octanol/toluene (40:60) as a function of the initial nitric acid concentration of the aqueous phase $\left(\boldsymbol{\square}=D_{\mathrm{Am}}, \boldsymbol{\Delta}=D_{\mathrm{Cm}}, \bullet=\mathrm{SF}_{\mathrm{Am} / \mathrm{Cm}}\right.$, contact time $=6$ hours at $\left.250 \mathrm{rpm}, \mathrm{T}=22^{\circ} \mathrm{C}\right)$.

We then measured the variation in the extraction of $\mathrm{Am}(\mathrm{III})$ and $\mathrm{Cm}(\mathrm{III})$ with contact time to check if the extraction system was at equilibrium. The extraction of Am(III) and Cm(III) from 2.4 $\mathrm{M} \mathrm{HNO}_{3}$ by $\mathrm{CyMe}_{4}-\mathrm{BTPhen} 3$ in octanol/toluene $(40: 60)$ at different contact times is presented in Figure 6. It can be seen that the $D$ values were still increasing after 6 hours of contact, and thus equilibrium had not been reached. Equilibrium extraction of Am(III) and $\mathrm{Cm}$ (III) was not achieved even after 22 hours of phase mixing under these conditions. This is partially due to the slow shaking speed used in the extraction experiments $(250 \mathrm{rpm})$. Thus it became apparent that the selectivity observed above in Figure 5 was thus not one that exists at equilibrium, but one that is due to the faster rates of extraction of Am(III) by CyMe $4-\mathrm{BTPhen}^{3}$ 
than $\mathrm{Cm}(\mathrm{III})$ and is therefore a kinetic effect. Nevertheless, a very promising separation factor for $\mathrm{Am}$ (III) over $\mathrm{Cm}$ (III) of 7.9 was observed after 10 hours of phase contact (Figure 6).

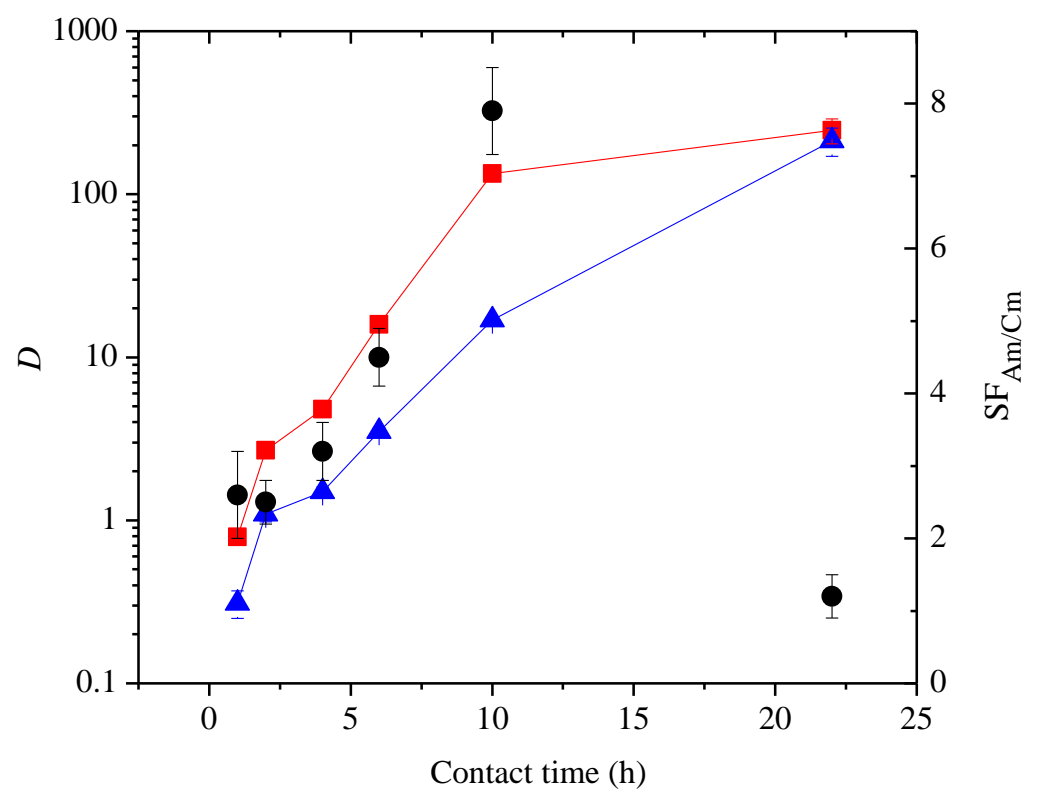

Figure 6. Selective extraction of Am(III) over Cm(III) from $2.4 \mathrm{M}$ nitric acid by $0.005 \mathrm{M}$ solutions of $\mathrm{CyMe}_{4}-\mathrm{BTPhen} 3$ in 1-octanol/toluene (40:60) as a function of contact time $(\mathbf{a}=$ $D_{\mathrm{Am}}, \boldsymbol{\Lambda}=D_{\mathrm{Cm}}, \bullet=\mathrm{SF}_{\mathrm{Am} / \mathrm{Cm}}$, mixing at $\left.250 \mathrm{rpm}, \mathrm{T}=22^{\circ} \mathrm{C}\right)$.

In a further set of kinetics experiments, we reduced the concentration of $\mathrm{CyMe}_{4}-\mathrm{BTPhen} 3$ to $0.001 \mathrm{M}$ in order to reduce the $D$ values observed in Figure 6, and changed the shaking speed to 1,800 rpm (Heidolph Multi Reax orbital shaker) to achieve more intensive phase mixing. Under these conditions, equilibrium extraction of $\mathrm{Am}$ (III) and $\mathrm{Cm}$ (III) was reached after 6 hours of shaking, and a maximum selectivity for Am(III) over Cm(III) was observed after 20 minutes of contact $\left(\mathrm{SF}_{\mathrm{Am} / \mathrm{Cm}}=4.0\right.$, see Supporting Information). As above, a trend of first increasing $\mathrm{SF}_{\mathrm{Am} / \mathrm{Cm}}$ values, then decreasing $\mathrm{SF}_{\mathrm{Am} / \mathrm{Cm}}$ values with contact time was found, supporting the proposal that the selectivity of $\mathrm{CyMe}_{4}-\mathrm{BTPhen} 3$ for $\mathrm{Am}$ (III) over $\mathrm{Cm}$ (III) arises due to the 
faster rates of extraction of Am(III) by the ligand. We also measured the separation of Am(III) from $\mathrm{Eu}(\mathrm{III})$ by $\mathrm{CyMe}_{4}-\mathrm{BTPhen} 3$ under these conditions and found that a highly effective separation of $\mathrm{Am}(\mathrm{III})$ from $\mathrm{Eu}(\mathrm{III})$ was achieved at the lower ligand concentration of $0.001 \mathrm{M}$, in

agreement with our previous work. ${ }^{\mathrm{XX}}$ Under these conditions, $D_{\mathrm{Am}}>1, D_{\mathrm{Eu}}<1$ and $\mathrm{SF}_{\mathrm{Am} / \mathrm{Eu}}$ of up to 228 was found (see Supporting Information). Confirmation that $\mathrm{Eu}(\mathrm{III})$ was being extracted as a 1:2 M:L complex was obtained by measuring the dependence of $\log D_{\mathrm{Eu}}$ on $\log \left[\mathrm{CyMe}_{4-}\right.$ BTPhen 3], which gave a straight line with a slope of $1.9\left(\mathrm{R}^{2}=0.9998\right.$, see Supporting Information), in agreement with our previous results. ${ }^{X X}$ REF NEEDED

Separation of Am(III) from Cm(III) by hydrophobic ligands in cyclohexanone. Having studied the separation of $\mathrm{Am}(\mathrm{III})$ from $\mathrm{Cm}(\mathrm{III})$ by $\mathrm{CyMe}_{4}-\mathrm{BTPhen} 3$ in 1-octanol and 1octanol/toluene mixtures, we next elected to study the extraction of Am(III) and $\mathrm{Cm}$ (III) by $\mathrm{CyMe}_{4}-\mathrm{BTPhen} 3$ using cyclohexanone as the diluent. This diluent has been suggested for processing spent nuclear fuels and has the advantage that extraction equilibrium is achieved much more rapidly than with 1 -octanol. ${ }^{20}$ The extraction of Am(III) and $\mathrm{Cm}(\mathrm{III})$ by $\mathrm{CyMe}_{4-}$ BTPhen 3 in cyclohexanone as a function of the nitric acid concentration of the aqueous phase is presented in Figure 7. 


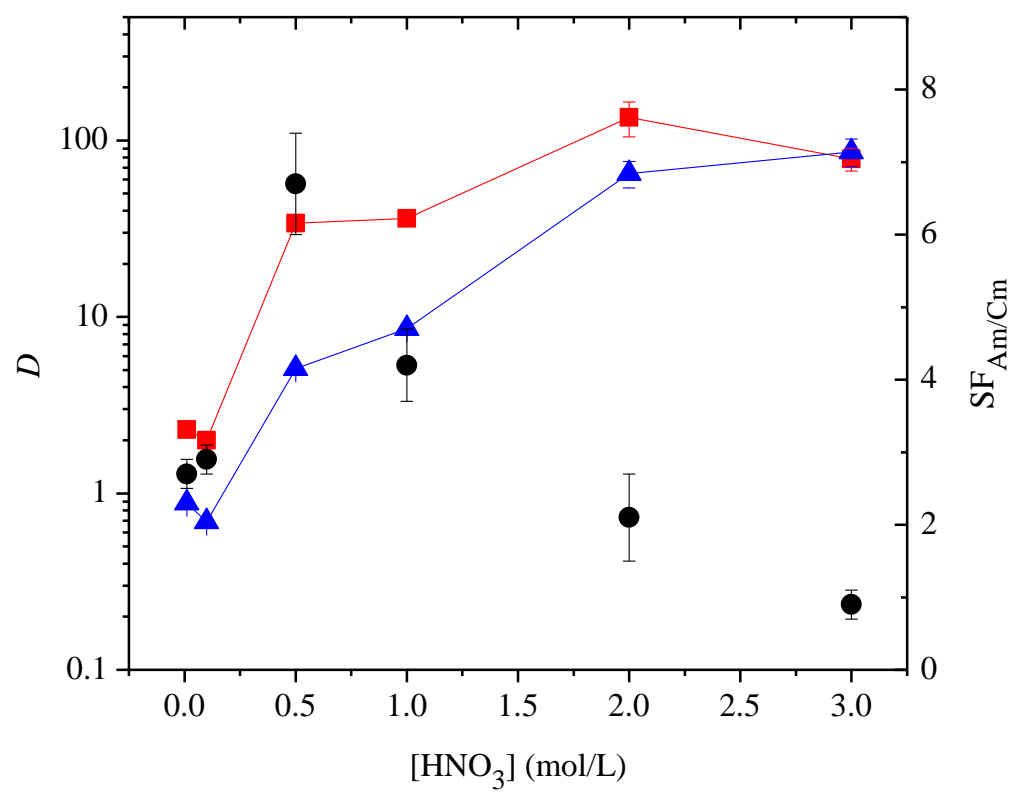

Figure 7. Selective extraction of Am(III) over $\mathrm{Cm}$ (III) from nitric acid by solutions of $\mathrm{CyMe}_{4}-$ BTPhen 3 in cyclohexanone $(0.005 \mathrm{M})$ as a function of the initial nitric acid concentration of the aqueous phase $\left(\boldsymbol{\bullet}=D_{\mathrm{Am}}, \boldsymbol{\Delta}=D_{\mathrm{Cm}}, \bullet=\mathrm{SF}_{\mathrm{Am} / \mathrm{Cm}}\right.$, contact time $=7$ minutes at $250 \mathrm{rpm}, \mathrm{T}=22$ $\left.{ }^{\circ} \mathrm{C}\right)$.

As shown, Am(III) is preferentially extracted over $\mathrm{Cm}(\mathrm{III})$ across a range of nitric acid concentrations. The highest selectivities for $\mathrm{Am}$ (III) over $\mathrm{Cm}$ (III) were observed in $0.5 \mathrm{M} \mathrm{HNO}_{3}$ and in 1.0 $\mathrm{M} \mathrm{HNO}_{3}$, with separation factors for $\mathrm{Am}(\mathrm{III})$ over $\mathrm{Cm}(\mathrm{III})$ of 6.7 and 4.2, respectively. These selectivities are comparable to those previously observed with a 5-bromosubstituted BTPhen ligand in 1-octanol, ${ }^{\text {Reference }} 24$ in rejected $\mathrm{Am} / \mathrm{Cm}$ separation paper (ACS Version) and underline the potential utility of the BTPhen ligands for the difficult separation of Am(III) from $\mathrm{Cm}(\mathrm{III})$.

Having identified the optimum nitric acid concentrations of the aqueous phase, we then examined the influence of contact time on the separation of $\mathrm{Am}(\mathrm{III})$ and $\mathrm{Cm}(\mathrm{III})$ by $\mathrm{CyMe}_{4}-$ 
BTPhen 3. The extraction of $\mathrm{Am}(\mathrm{III})$ and $\mathrm{Cm}(\mathrm{III})$ from $0.5 \mathrm{M} \mathrm{HNO}$ by solutions of 3 in cyclohexanone $(0.005 \mathrm{M})$ as a function of contact time is presented in Figure 8 . The distribution ratio for $\mathrm{Am}(\mathrm{III})$ rises more rapidly than that of $\mathrm{Cm}(\mathrm{III})$ with contact time, resulting in a further enhancement of the separation factor for Am(III) over $\mathrm{Cm}(\mathrm{III})$ in the initial stages of extraction. This indicates that Am(III) is extracted more rapidly than $\mathrm{Cm}(\mathrm{III})$. A maximum selectivity for $\mathrm{Am}(\mathrm{III})$ over $\mathrm{Cm}(\mathrm{III})$ was observed after 7 minutes of contact $\left(\mathrm{SF}_{\mathrm{Am} / \mathrm{Cm}}=5.5\right)$ and the selectivity for $\mathrm{Am}(\mathrm{III})$ over $\mathrm{Cm}$ (III) decreased thereafter. Lower selectivities for Am(III) over Cm(III) were observed when the concentration of 3 was $0.001 \mathrm{M}\left(\mathrm{SF}_{\mathrm{Am} / \mathrm{Cm}} \leq 2.5\right.$, see Supporting Information).

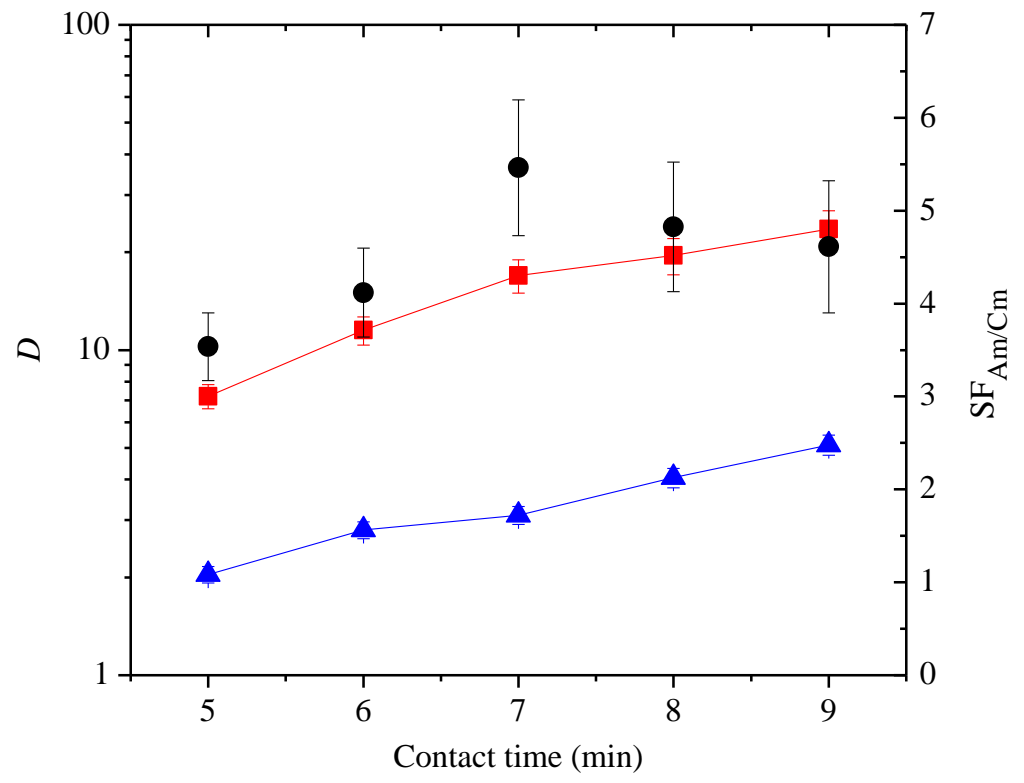

Figure 8. Selective extraction of $\mathrm{Am}(\mathrm{III})$ over $\mathrm{Cm}(\mathrm{III})$ from $0.5 \mathrm{M}$ nitric acid by solutions of CyMe 4 -BTPhen 3 in cyclohexanone $(0.005 \mathrm{M})$ as a function of contact time $\left(\mathbf{\square}=D_{\mathrm{Am}}, \boldsymbol{\Delta}=D_{\mathrm{Cm}}\right.$, - $=\mathrm{SF}_{\mathrm{Am} / \mathrm{Cm}}$, mixing at $\left.250 \mathrm{rpm}, \mathrm{T}=22^{\circ} \mathrm{C}\right)$.

We then explored the extraction of $\mathrm{Am}(\mathrm{III})$ and $\mathrm{Cm}(\mathrm{III})$ from $1 \mathrm{M} \mathrm{HNO}_{3}$ by solutions of $\mathrm{CyMe}_{4}-\mathrm{BTPhen} 3$ at longer contact times. The results are shown in Figure 9. Again, Am(III) was more rapidly extracted than $\mathrm{Cm}(\mathrm{III})$, and the separation factor for $\mathrm{Am}(\mathrm{III})$ over $\mathrm{Cm}(\mathrm{III})$ riose to a 
maximum of 4.8 after 10 minutes of contact before decreasing again to 1.0 after 120 minutes of contact (presumably at equilibrium). The initial increase in $\mathrm{SF}_{\mathrm{Am} / \mathrm{Cm}}$ with contact time was even more pronounced in $1 \mathrm{M} \mathrm{HNO}_{3}$ than in $0.5 \mathrm{M} \mathrm{HNO}_{3}$ (Figure 8). Thus the separation of $\mathrm{Am}(\mathrm{III})$ from $\mathrm{Cm}$ (III) observed here in cyclohexanone appears to be due to a kinetic effect that is emphasised at short contact times. To our knowledge, this is the first time that such a kinetic effect has been demonstrated in the separation of two metal ions by bis-(1,2,4)-triazine ligands.

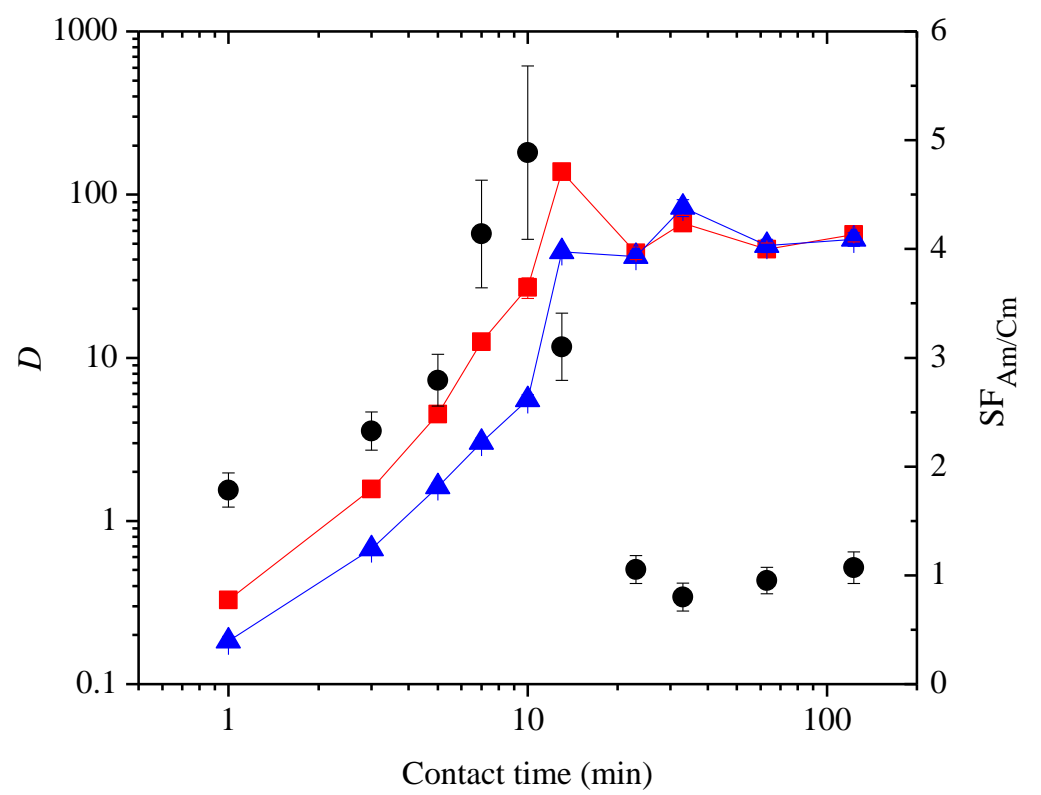

Figure 9. Selective extraction of $\mathrm{Am}$ (III) over $\mathrm{Cm}$ (III) from $1 \mathrm{M}$ nitric acid by solutions of $\mathrm{CyMe}_{4}-\mathrm{BTPhen} 3$ in cyclohexanone $(0.005 \mathrm{M})$ as a function of contact time $\left(\mathbf{\square}=D_{\mathrm{Am}}, \mathbf{\Delta}=D_{\mathrm{Cm}}\right.$, - $=\mathrm{SF}_{\mathrm{Am} / \mathrm{Cm}}$, mixing at $\left.250 \mathrm{rpm}, \mathrm{T}=20 \pm 1^{\circ} \mathrm{C}\right)$.

We next studied the previously reported BTPhen ligands C4-BTPhen $4^{21}$ and C5-BTPhen

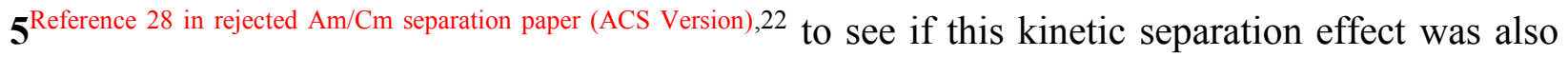
observed in other BTPhen ligands. The extraction of Am(III) and Cm(III) from $0.5 \mathrm{M} \mathrm{HNO}_{3}$ by solutions of C4-BTPhen $\mathbf{4}$ in cyclohexanone as a function of contact time is shown in Figure 10. 
BTPhen ligand 4 did not show the same kinetic effect at short contact times as $\mathrm{CyMe}_{4}-\mathrm{BTPhen}$ 3, and was generally not as selective for $\mathrm{Am}(\mathrm{III})$ over $\mathrm{Cm}(\mathrm{III})$ as $\mathbf{3}\left(\mathrm{SF}_{\mathrm{Am} / \mathrm{Cm}} \leq 3.1\right)$.

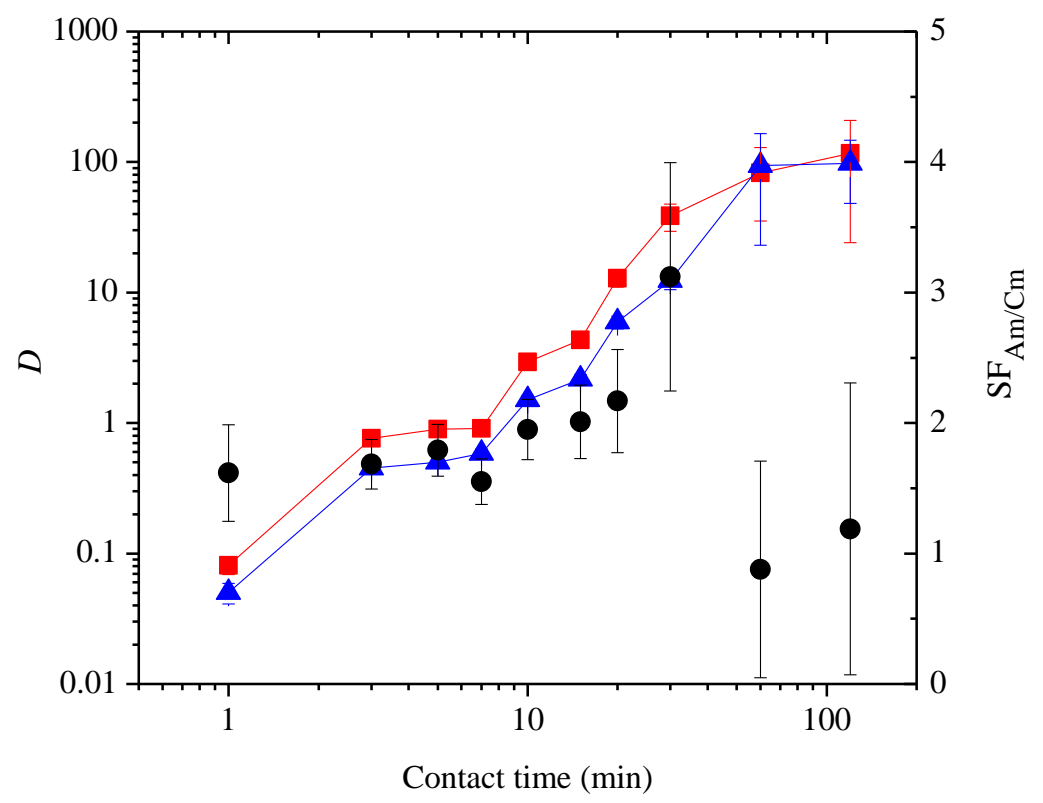

Figure 10. Selective extraction of $\mathrm{Am}$ (III) over $\mathrm{Cm}$ (III) from $0.5 \mathrm{M}$ nitric acid by solutions of C4-BTPhen 4 in cyclohexanone $(0.005 \mathrm{M})$ as a function of contact time $\left(\boldsymbol{\bullet}=D_{\mathrm{Am}}, \boldsymbol{\Lambda}=D_{\mathrm{Cm}}, \bullet=\right.$ $\mathrm{SF}_{\mathrm{Am} / \mathrm{Cm}}$, mixing at $250 \mathrm{rpm}, \mathrm{T}=22^{\circ} \mathrm{C}$ ).

Similar results were observed with the C5-BTPhen ligand 5 (Figure 11). The separation factor for $\mathrm{Am}(\mathrm{III})$ over $\mathrm{Cm}(\mathrm{III})$ increased slightly with contact time and reached a maximum value of 2.6 after 30 minutes of phase contact. Thus the initial increase in the separation selectivity for Am(III) over Cm(III) with contact time appears to be dependent on the structure of the alkyl side groups appended to the triazine rings in BTPhen ligands. 




Figure 11. Selective extraction of $\mathrm{Am}(\mathrm{III})$ over $\mathrm{Cm}$ (III) from $0.5 \mathrm{M}$ nitric acid by solutions of C5-BTPhen 5 in cyclohexanone $(0.005 \mathrm{M})$ as a function of contact time $\left(\boldsymbol{\square}=D_{\mathrm{Am}}, \boldsymbol{\Delta}=D_{\mathrm{Cm}}, \bullet=\right.$ $\mathrm{SF}_{\mathrm{Am} / \mathrm{Cm}}$, mixing at $250 \mathrm{rpm}, \mathrm{T}=22^{\circ} \mathrm{C}$ ).

The high selectivities for $\mathrm{Am}(\mathrm{III})$ over $\mathrm{Cm}$ (III) observed above under non-equilibrium conditions with $\mathrm{CyMe}_{4}-\mathrm{BTPhen} 3$ in 1-octanol or 1-octanol/toluene mixtures at long contact times, or in cyclohexanone at short contact times, could form the basis of an improved process for separating Am(III) from $\mathrm{Cm}(\mathrm{III})$ in future spent nuclear fuel reprocessing. Notably, such kinetic separations have been proposed previously for separating similar metal ions, or even isotopes of the same metal ion. The kinetic separation of ${ }^{235} \mathrm{U}(\mathrm{VI})$ from ${ }^{238} \mathrm{U}(\mathrm{VI})$ during liquidliquid extraction, or its sorption onto cation exchangers, has been previously reported, ${ }^{23}$ and separation factors for ${ }^{235} \mathrm{U}(\mathrm{VI})$ over ${ }^{238} \mathrm{U}(\mathrm{VI})$ of up to 1.01 were achieved. Even with this modest selectivity, the industrial applicability of the isotope separation was demonstrated to be both technologically and economically feasible. ${ }^{24}$ The kinetic separation of Co(II) from Ni(II) using 
cation exchangers has also been reported, giving separation factors of up to $1.1 .^{25} \mathrm{~A}$ prominent example of the utility of kinetic effects in metal separations is the use of 8-hydroxyquinolines such as the commercially available Kelex $100^{\circledR}$ in hydrometallurgy. These reagents efficiently separate $\mathrm{Cu}(\mathrm{II})$ from $\mathrm{Fe}(\mathrm{III})$ at short mixing times due to the significantly faster rates of extraction of $\mathrm{Cu}(\mathrm{II})$ into organic diluents. ${ }^{26}$ The separation selectivities for $\mathrm{Am}$ (III) over $\mathrm{Cm}$ (III) observed above for $\mathrm{CyMe}_{4}$-BTPhen 3 in both diluent systems (1-octanol and 1-octanol/toluene, and cyclohexanone) are significantly larger than the above values, and compare favorably to those reported previously in other methods proposed for separating $\mathrm{Am}(\mathrm{III})$ from $\mathrm{Cm}(\mathrm{III}) .{ }^{\mathrm{XX}-\mathrm{XX}}$

The exact origin of the above separation of $\mathrm{Am}$ (III) from $\mathrm{Cm}$ (III) under kinetic conditions is not fully understood at this point. It is well known that the structures and metal:ligand stoichiometries of the $\mathrm{Am}(\mathrm{III})$ and $\mathrm{Cm}(\mathrm{III})$ complexes formed with a given bis-(1,2,4)-triazine ligand under extraction relevant conditions are identical. The metal-ligand bonding in these complexes is believed to have a significant covalent contribution, ${ }^{27}$ and recent experimental evidence from ${ }^{15} \mathrm{~N}$ NMR and TRLFS measurements support this hypothesis. ${ }^{28}$ Hydrophobic BTPs form 1:3 metal:ligand complexes with both Am(III) and $\mathrm{Cm}(\mathrm{III})$ as revealed by both EXAFS and TRLFS studies, respectively. ${ }^{29}$ The average $\mathrm{M}-\mathrm{N}$ bond lengths in these Am(III) and Cm(III) 1:3 BTP complexes are nearly identical (the slightly higher $\mathrm{M}-\mathrm{N}$ bond length in the $\mathrm{Cm}$ (III) complex is attributed to its slightly smaller ionic radius). Furthermore, differences in extraction selectivity between $\mathrm{Cm}$ (III) and $\mathrm{Eu}(\mathrm{III})$ are based on the different thermodynamic stabilities of their 1:3 complexes with BTPs, and not on structural differences between their respective complexes. ${ }^{36,37}$ The same holds true for the tetradentate bis-(1,2,4)-triazine ligands. Both hydrophobic and hydrophilic BTBPs form 1:2 metal:ligand complexes with Cm(III) and Eu(III) as shown by TRLFS studies. ${ }^{30}$ In addition, CyMe 4 -BTPhen 3 and CyMe 4 -BTBP 2 both 
form identical 1:2 complexes with $\mathrm{Cm}(\mathrm{III})$ as shown by TRLFS studies, ${ }^{31}$ while $\mathrm{CyMe}_{4}-\mathrm{BTBP} 2$ forms a 1:2 complex with Am(III) as shown by EXAFS studies. ${ }^{32}$ A single bidentate nitrate ion completes the inner coordination sphere in the $\mathrm{Am}$ (III) and $\mathrm{Cm}(\mathrm{III}) 1: 2$ complexes of both ligands $\mathbf{2}$ and $\mathbf{3}$, which is in agreement with the solution and solid state structures of the corresponding lanthanide(III) complexes of 2 and $3 .^{33}$ It thus seems likely that in the present study, $\mathrm{CyMe}_{4}-\mathrm{BTPhen} 3$ forms structurally identical 1:2 complexes with both Am(III) and $\mathrm{Cm}(\mathrm{III})$, and that the kinetic effect observed above is not due to differences in the structures of the extracted complexes. However, it is unclear at this point if the diluent is playing any role in this kinetic effect, for instance through preferential formation of ternary complexes.

A more likely explanation for the observed kinetic effect is based on differences in the kinetic labilities of the Am(III) and Cm(III) aqua complexes toward ligand substitution. It is well known that the water exchange rate constants of the trivalent lanthanide aqua complexes decrease on going from left to right [from $\mathrm{Gd}(\mathrm{III})$ to $\mathrm{Yb}(\mathrm{III}))]$ across the lanthanide series, in accordance with the decreasing ionic radius of the later lanthanides (the lanthanide contraction). ${ }^{34}$ The aqua ions at the beginning of the series are thus more kinetically labile towards substitution than those at the end. However, equivalent data for actinide aqua complexes are very scarce, and limited only to studies on U(VI) and Th(IV). ${ }^{35}$ To the best of our knowledge, no data exist on the rates of water exchange of $\mathrm{Am}(\mathrm{III})$ and $\mathrm{Cm}(\mathrm{III})$ aqua complexes. However, assuming a linear correlation with the lanthanides based on cation radius, the second order water exchange rates for Am(III)$\mathrm{Cf}(\mathrm{III})$ are estimated to range from $1 \times 10^{9}$ to $1 \times 10^{8} \mathrm{M}^{-1} \mathrm{~s}^{-1}$. ${ }^{36}$ Since the ionic radius of $\mathrm{Cm}$ (III) is slightly lower than that of $\mathrm{Am}(\mathrm{III})\left(1.105 \AA\right.$ versus $1.122 \AA$, respectively), ${ }^{12}$ it seems reasonable to assume that the same trend in water exchange rates observed in the lanthanide series will hold true for the trivalent actinides, and that the Am(III) aqua complex will thus be 
more kinetically labile than the $\mathrm{Cm}(\mathrm{III})$ aqua complex. This would mean that the Am(III) aqua complex will undergo ligand substitution with $\mathrm{CyMe}_{4}-\mathrm{BTPhen} \mathbf{3}$ at the interface more rapidly than the $\mathrm{Cm}(\mathrm{III})$ aqua complex under kinetic conditions, resulting in a more rapid extraction of $\mathrm{Am}(\mathrm{III})$ than $\mathrm{Cm}(\mathrm{III})$ as observed above. It is also notable that the relative rates of oxidation of unstable $\mathrm{Am}(\mathrm{II})$ and $\mathrm{Cm}$ (II) in aqueous solution to the corresponding trivalent ions follow this same trend, with $\mathrm{Am}$ (II) reacting more rapidly than $\mathrm{Cm}$ (II) $\left(9.7 \times 10^{4} \mathrm{~s}^{-1}\right.$ versus $6 \times 10^{4} \mathrm{~s}^{-1}$, respectively). ${ }^{37}$

This leaves the question of why the above kinetic separation of Am(III) from Cm(III) using cyclohexanone as the diluent is only observed with $\mathrm{CyMe}_{4}-\mathrm{BTPhen} \mathbf{3}$ and not BTPhens $\mathbf{4}$ and $\mathbf{5}$. Clearly, the structure of the alkyl side-chains appended to the outer 1,2,4-triazine rings is having an effect on the selectivity of the extraction. It was previously observed in studies on BTPs that branching at the benzylic positions of the alkyl groups leads to a higher selectivity in the extraction of Am(III) over Eu(III). ${ }^{38}$ This effect was attributed to reduced coordination of water molecules to the metal in the 1:3 BTP complexes containing bulky branched alkyl groups compared to those containing non-bulky linear alkyl groups, which leads to an extractable 1:3 complex with a more hydrophobic exterior, and a lower likelihood of substitution of the coordinated BTP ligands by aqua ligands. This effect is maximised in the highly branched $\mathrm{CyMe}_{4}-\mathrm{BTP} 1$, which has one of the highest $\mathrm{Am}(\mathrm{III}) / \mathrm{Eu}(\mathrm{III})$ selectivities for any BTP ligand reported to date $\left(\mathrm{SF}_{\mathrm{Am} / \mathrm{Eu}}=5000\right)$. It is thus likely that the same effect is observed above with $\mathrm{CyMe}_{4}-\mathrm{BTPhen} \mathbf{3}$. Thus we propose that $\mathbf{3}$ forms a more hydrophobic 1:2 complex with Am(III) more rapidly than $\mathrm{Cm}(\mathrm{III})$, resulting in the rapid and selective Am(III) extraction observed above. In contrast, BTPhens 4 and 5 bearing linear alkyl groups form Am(III) and Cm(III) 1:2 complexes with a less hydrophobic exterior than that formed by $\mathbf{3}$, and thus the opportunity for a 
more rapid extraction of $\mathrm{Am}(\mathrm{III})$ than $\mathrm{Cm}(\mathrm{III})$ is lost, leading to a lower separation factor for Am(III) over Cm(III) with these ligands.

Separation of Am(III) from Cm(III) by hydrophilic ligands in nitric acid. We previously showed that hydrophilic tetrasulfonated bis-(1,2,4)-triazine ligands 7-10 (Figure 2) were capable of separating $\mathrm{Am}(\mathrm{III})$ from $\mathrm{Eu}(\mathrm{III})$ via selective $\mathrm{Am}(\mathrm{III})$ complex formation in aqueous nitric acid, leading to highly efficient separations of $\mathrm{Am}(\mathrm{III})$ from $\mathrm{Eu}(\mathrm{III})$ when the $O$-donor ligand $N, N, N^{\prime}, N^{\prime}$-tetraoctyldiglycolamide (TODGA) was used as the hydrophobic extractant in the organic phase. ${ }^{\mathrm{XX}}$ TODGA is the preferred European ligand for the non-selective co-extraction of actinides and lanthanides from PUREX raffinate. ${ }^{39}$ We now report our results on the ability of these ligands, together with the disulfonated BTBP and BTP ligands 11 and $\mathbf{1 2}$ shown in Figure 12, to separate Am(III) from $\mathrm{Cm}(\mathrm{III})$ in this two-ligand system.

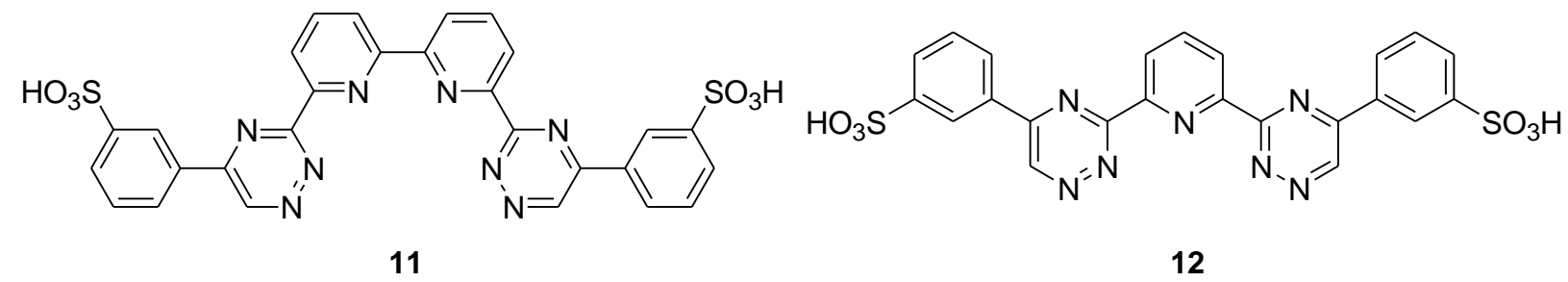

Figure 12. Hydrophilic disulfonated BTBP ligand 11 and BTP ligand $\mathbf{1 2}$ for selective actinide aqueous complexation in nitric acid.

The sulfonated ligands 7-12 were evaluated for their ability to suppress selectively (mask) the extraction of Am(III) and Cm(III) from nitric acid solutions by TODGA. Each of the sulfonated ligands $(0.01 \mathrm{M})$ was added to $\mathrm{HNO}_{3}$ solutions of different concentrations which were spiked with $\mathrm{Am}(\mathrm{III})$ and $\mathrm{Cm}(\mathrm{III})$ tracers, and the distribution ratios and separation factors were measured after contacting these aqueous phases with organic solutions containing TODGA $(0.2$ M) in kerosene/octanol (volume ratio 95:5). These results were compared to that of a blank 
experiment, which did not contain any sulfonated ligand in the aqueous phase. Due to the rapid extraction kinetics of TODGA, the results reported here are necessarily under equilibrium conditions. The results for sulfonated ligands 7, 9 and $\mathbf{1 0}$ in $0.28 \mathrm{M} \mathrm{HNO}_{3}$ are shown in Figure 13.

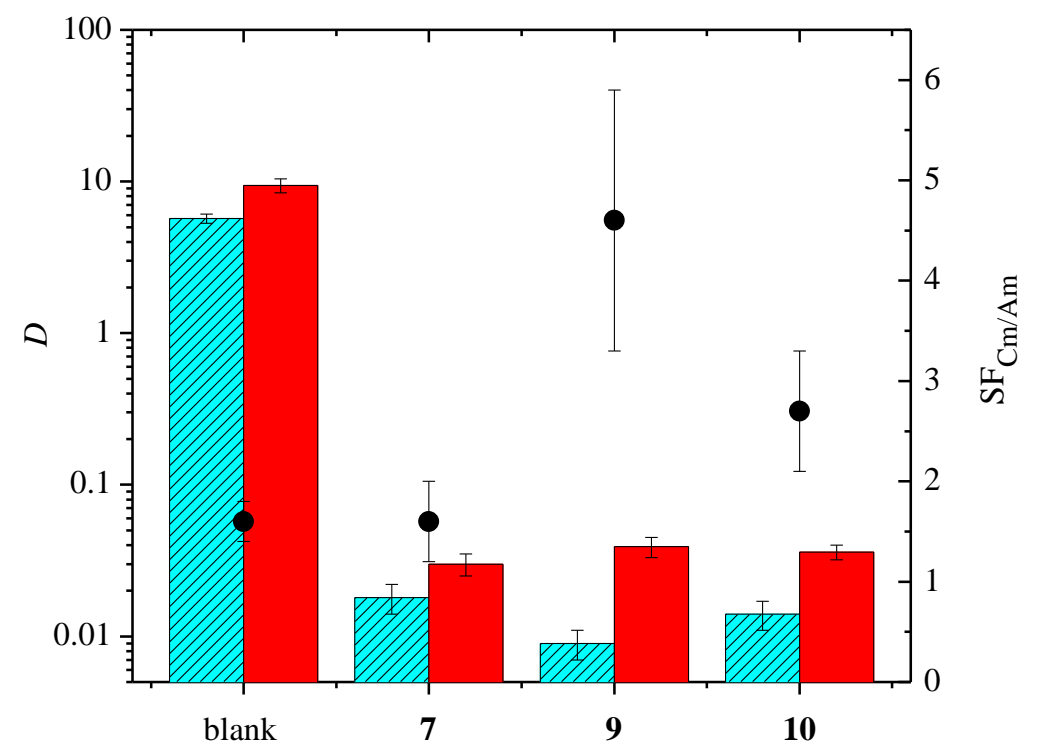

Figure 13. Extraction of $\mathrm{Am}(\mathrm{III})$ and $\mathrm{Cm}(\mathrm{III})$ from $0.28 \mathrm{M}$ nitric acid by solutions of TODGA $(0.2 \mathrm{M})$ in 1-octanol/kerosene (5:95) in the absence and presence of hydrophilic sulfonated bis$(1,2,4)$-triazine ligands $\mathbf{7 - 1 0}(0.01 \mathrm{M})$ in the aqueous phase (dashed blue bar $=D_{\mathrm{Am}}$, clear red bar $=D_{\mathrm{Cm}}, \bullet=\mathrm{SF}_{\mathrm{Cm} / \mathrm{Am}}$, contact time $=6$ hours at $\left.250 \mathrm{rpm}, \mathrm{T}=22^{\circ} \mathrm{C}\right)$.

As expected, the extraction of $\mathrm{Am}(\mathrm{III})$ and $\mathrm{Cm}$ (III) into the organic phase by TODGA was suppressed by each of the tetrasulfonated ligands 7, 9 and 10, and the $D$ values for Am(III) and $\mathrm{Cm}$ (III) subsequently decreased to below 0.1 compared to that of the blank sample. This is in agreement with our previous studies on $\mathrm{Am}(\mathrm{III}) / \mathrm{Eu}(\mathrm{III})$ separation by the tetrasulfonated ligands 7-10. ${ }^{\mathrm{XX}}$ Compared to the blank sample, the separation factors for $\mathrm{Cm}(\mathrm{III})$ over Am(III) increased 
slightly in the case of tetrasulfonated BTPhen ligands $\mathbf{9}$ and $\mathbf{1 0}$, which differ only in the counterion used $\left(\mathrm{Na}^{+} \mathrm{v} \mathrm{H}{ }^{+}\right)$. With tetrasulfonated BTPhen 9, a significantly high separation factor for $\mathrm{Cm}$ (III) over Am(III) of 4.6 was observed.

The results for the extraction of $\mathrm{Am}(\mathrm{III})$ and $\mathrm{Cm}(\mathrm{III})$ from $0.5 \mathrm{M} \mathrm{HNO}_{3}$ by TODGA in the absence and presence of sulfonated ligands 7-12 in the aqueous phase are presented in Figure 14. The tetrasulfonated ligands $\mathbf{7 - 1 0}$ all suppress the extraction of Am(III) and Cm(III) by TODGA, giving lower $D$ values compared to those observed in the blank sample. In contrast, the disulfonated ligands 11 and 12 were unable to suppress the extraction of either metal, and the $D$ values and separation factors were virtually identical to those of the blank experiment. This agrees with our earlier work on $\mathrm{Am}(\mathrm{III}) / \mathrm{Eu}(\mathrm{III})$ separation with these ligands, where we found the same marked difference in selective complexation performance between tetrasulfonated ligands and their disulfonated counterparts. ${ }^{X X}$ For the tetrasulfonated ligands $\mathbf{7 - 1 0}$, the separation factors for $\mathrm{Cm}(\mathrm{III})$ over $\mathrm{Am}(\mathrm{III})$ all increased compared to that in the blank experiment, indicating that they complex Am(III) more strongly than $\mathrm{Cm}(\mathrm{III})$ in the aqueous phase, and $\mathrm{Cm}(\mathrm{III})$ is more easily extracted. The selectivity is highest for the tetrasulfonated BTPhens 9 and $10\left(\mathrm{SF}_{\mathrm{Cm} / \mathrm{Am}}=4.6\right.$ for $\mathbf{9}, \mathrm{SF}_{\mathrm{Cm} / \mathrm{Am}}=3.2$ for 10). With ligand $\mathbf{9}$, a feasible separation could be achieved as $D_{\mathrm{Cm}}>1$ and $D_{\mathrm{Am}}<1$ (Figure 14). 


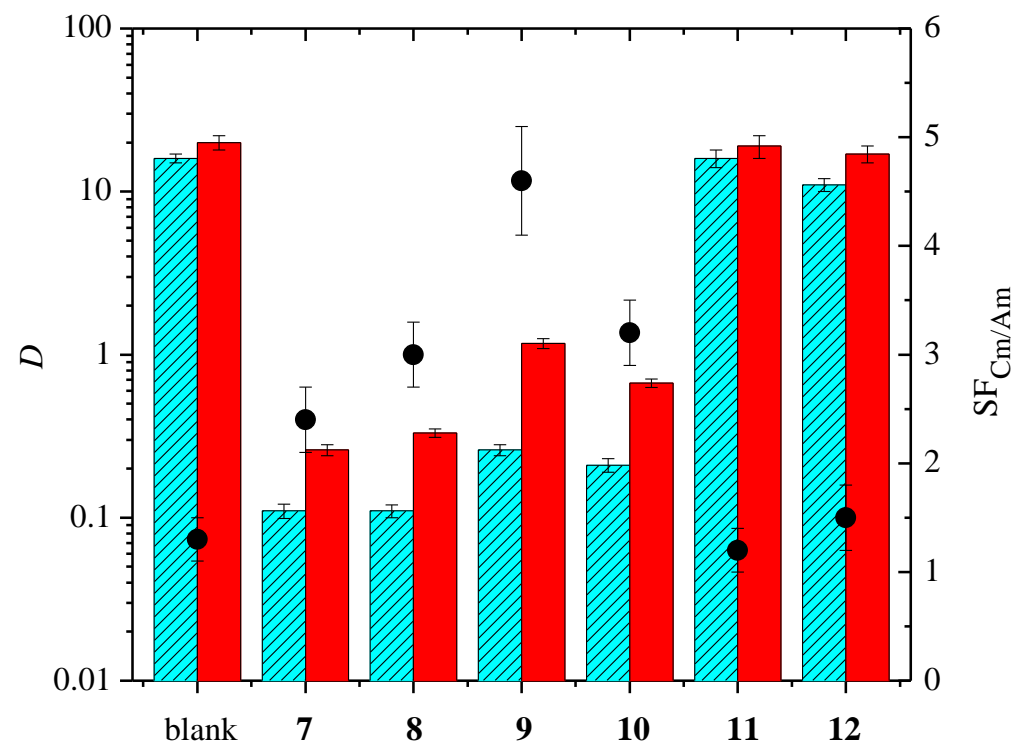

Figure 14. Extraction of $\mathrm{Am}(\mathrm{III})$ and $\mathrm{Cm}(\mathrm{III})$ from $0.5 \mathrm{M}$ nitric acid by solutions of TODGA $(0.2 \mathrm{M})$ in 1-octanol/kerosene $(5: 95)$ in the absence and presence of hydrophilic sulfonated bis$(1,2,4)$-triazine ligands $\mathbf{7 - 1 2}(0.01 \mathrm{M})$ in the aqueous phase (dashed blue bar $=D_{\text {Am, }}$ clear red bar $=D_{\mathrm{Cm}}, \bullet=\mathrm{SF}_{\mathrm{Cm} / \mathrm{Am}}$, contact time $=6$ hours at $\left.250 \mathrm{rpm}, \mathrm{T}=22^{\circ} \mathrm{C}\right)$.

We also studied the extraction of Am(III) and $\mathrm{Cm}$ (III) by TODGA from nitric acid solutions of higher acidity in the absence and presence of sulfonated ligands $\mathbf{7 - 1 2}$. In the extraction from 0.77 $\mathrm{M} \mathrm{HNO}_{3}$, the tetrasulfonated ligands 7-10 all showed higher separation factors for Cm(III) over Am(III) compared to the blank experiment. Once again, the BTPhen ligands 9 and 10 showed the higher separation factors compared to the BTBPs $\left(\mathrm{SF}_{\mathrm{Cm} / \mathrm{Am}}=3.3\right.$ for $\mathbf{9}, \mathrm{SF}_{\mathrm{Cm} / \mathrm{Am}}=3.4$ for 10, see Supporting Information). Similar results were observed in the extraction from $1.04 \mathrm{M}$ $\mathrm{HNO}_{3}$, although the $D$ values for both metals exceeded 1 making a practical separation less feasible at this acidity. Under these conditions, BTPhen 9 showed the highest selectivity $\left(\mathrm{SF}_{\mathrm{Cm} / \mathrm{Am}}=3.8\right.$, see Supporting Information). 
We and others have previously observed that the ability of hydrophilic sulfonated bis-(1,2,4)triazine ligands to suppress Am(III) by TODGA decreases as the nitric acid concentration of the aqueous phase increases, with optimum results being found when $\left[\mathrm{HNO}_{3}\right] \leq 0.5 \mathrm{M}^{\mathrm{XX}}$ Having identified the tetrasulfonated BTPhen ligands $\mathbf{9}$ and $\mathbf{1 0}$ as the best candidates for $\mathrm{Am}(\mathrm{III}) / \mathrm{Cm}$ (III) separation by hydrophilic ligands under thermodynamic conditions, we next studied the variation in the separation factor for $\mathrm{Cm}$ (III) over $\mathrm{Am}$ (III) with the nitric acid concentration of the aqueous phase. The results for BTPhen ligand $\mathbf{9}$ are shown in Figure 15 and the results for BTPhen ligand $\mathbf{1 0}$ are shown in Figure 16.

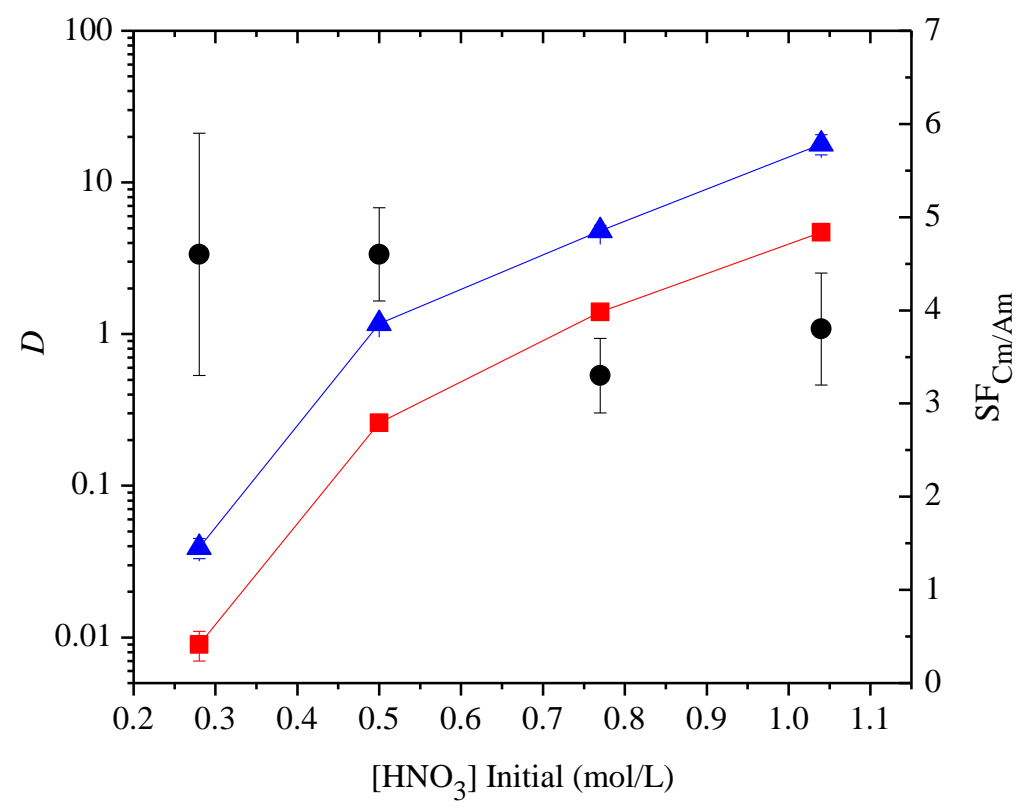

Figure 15. Extraction of $\mathrm{Am}(\mathrm{III})$ and $\mathrm{Cm}$ (III) from nitric acid solutions by solutions of TODGA $(0.2 \mathrm{M})$ in 1-octanol/kerosene $(5: 95)$ in the presence of hydrophilic tetrasulfonated BTPhen ligand $9(0.01 \mathrm{M})$ in the aqueous phase $\left(\boldsymbol{\square}=D_{\mathrm{Am}}, \boldsymbol{\Delta}=D_{\mathrm{Cm}}, \bullet=\mathrm{SF}_{\mathrm{Cm} / \mathrm{Am}}\right.$, contact time $=6$ hours at $250 \mathrm{rpm}, \mathrm{T}=22{ }^{\circ} \mathrm{C}$ ). 
As expected, the $D$ values for both $\mathrm{Am}(\mathrm{III})$ and $\mathrm{Cm}(\mathrm{III})$ increased with increasing $\left[\mathrm{HNO}_{3}\right]$ in both cases, in agreement with previous results. ${ }^{\mathrm{XX}}$ This could be becausethe extraction of metal ions by TODGA becomes more thermodynamically favoured as $\left[\mathrm{HNO}_{3}\right]$ increases due to the removal of nitrate ions from the aqueous phase. The separation factors for $\mathrm{Cm}$ (III) over Am(III) generally decrease as $\left[\mathrm{HNO}_{3}\right]$ increases, apart from BTPhen $\mathbf{1 0}$ where the selectivity increases up to $\left[\mathrm{HNO}_{3}\right]=0.77 \mathrm{M}$ (Figure 16). The highest separation factors are found in $0.28 \mathrm{M} \mathrm{HNO}_{3}$ and in $0.5 \mathrm{M} \mathrm{HNO}_{3}$ for BTPhen 9 (Figure 15), and in $0.28 \mathrm{M} \mathrm{HNO}_{3}, 0.5 \mathrm{M} \mathrm{HNO}_{3}$ and $0.77 \mathrm{M} \mathrm{HNO}_{3}$ for BTPhen 10 (Figure 16). We also studied the variation in $\mathrm{SF}_{\mathrm{Cm} / \mathrm{Am}}$ with $\left[\mathrm{HNO}_{3}\right]$ for tetrasulfonated BTBPs $\mathbf{7}$ and $\mathbf{8}$, and disulfonated ligands $\mathbf{1 1}$ and $\mathbf{1 2}$. Tetrasulfonated BTBPs $\mathbf{7}$ and $\mathbf{8}$ showed similar trends as the corresponding BTPhens $\mathbf{9}$ and 10, although the selectivities were generally lower $\left(\mathrm{SF}_{\mathrm{Cm} / \mathrm{Am}} \leq 3\right.$, see Supporting Information). The disulfonated ligands 11 and 12 did not show any significant selectivity for Cm(III) over Am(III).

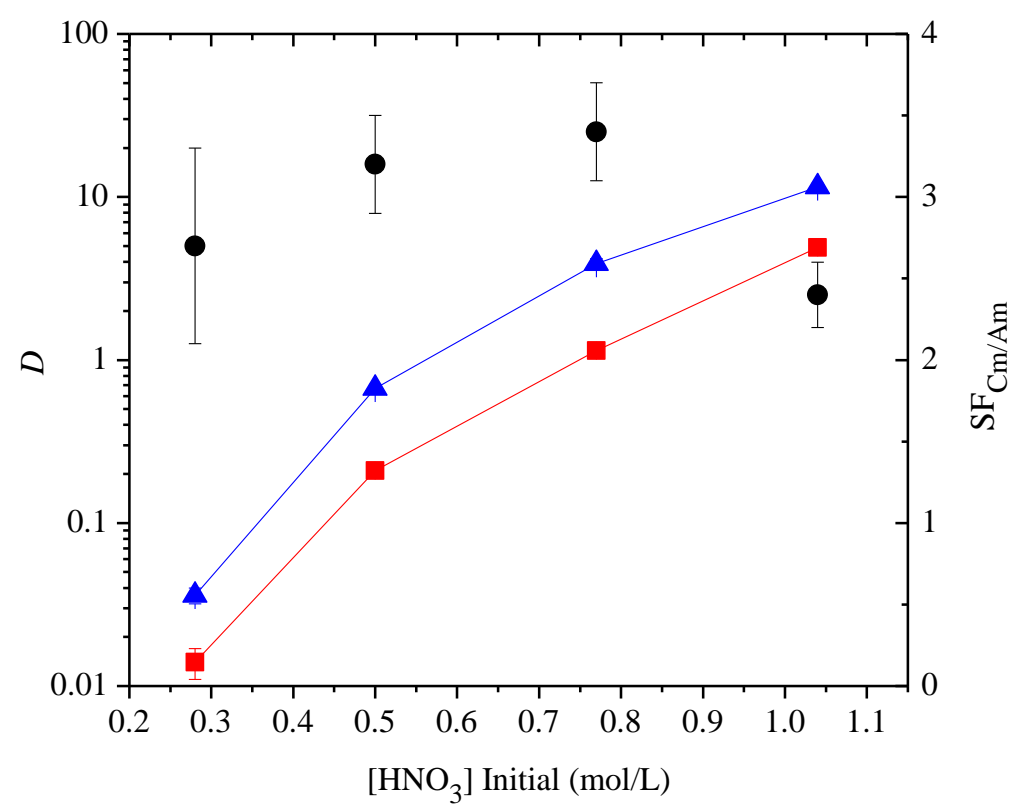


Figure 16. Extraction of $\mathrm{Am}(\mathrm{III})$ and $\mathrm{Cm}(\mathrm{III})$ from nitric acid solutions by solutions of TODGA $(0.2 \mathrm{M})$ in 1-octanol/kerosene $(5: 95)$ in the presence of hydrophilic tetrasulfonated BTPhen ligand $10(0.01 \mathrm{M})$ in the aqueous phase $\left(\boldsymbol{\square}=D_{\mathrm{Am}}, \boldsymbol{\Delta}=D_{\mathrm{Cm}}, \bullet=\mathrm{SF}_{\mathrm{Cm} / \mathrm{Am}}\right.$, contact time $=6$ hours at $250 \mathrm{rpm}, \mathrm{T}=22{ }^{\circ} \mathrm{C}$ ).

Thus, hydrophilic tetrasulfonated BTPhen ligands $\mathbf{9}$ and $\mathbf{1 0}$ also have the ability to separate Am(III) from $\mathrm{Cm}$ (III) via selective Am(III) complex formation in nitric acid, in agreement with previously reported results on BTPhen ligand 9. ${ }^{\mathrm{XX}}$ The higher selectivity of these pre-organized ligands for $\mathrm{Am}(\mathrm{III})$ over $\mathrm{Cm}(\mathrm{III})$ is in agreement with the results reported above for $\mathrm{CyMe}_{4}$ BTPhen 3 and other hydrophobic bis-(1,2,4)-triazine ligands. ${ }^{\mathrm{XX}}$ REF Tetrasulfonated BTP $\mathbf{6}^{\mathrm{XX}}$ is one of a number of hydrophilic ligands currently being developed as an actinide-selective stripping agent for use in a new minor actinide partitioning process in Europe ${ }^{40}$ Since the tetrasulfonated BTPhens $\mathbf{9}$ and $\mathbf{1 0}$ show higher separation factors for $\mathrm{Cm}(\mathrm{III})$ over $\mathrm{Am}(\mathrm{III})$ than 6, these ligands could represent a further refinement of this process by allowing for the simultaneous separation of $\mathrm{Am}(\mathrm{III})$ from $\mathrm{Cm}(\mathrm{III})$, as well as the separation of $\mathrm{Am}(\mathrm{III})$ and Cm(III) from the lanthanides.

Table 1. Summary of the separation factors for $\mathrm{Am}(\mathrm{III})$ over $\mathrm{Cm}(\mathrm{III})\left(\mathrm{SF}_{\mathrm{Am} / \mathrm{Cm}}\right.$, for hydrophobic ligands) and $\mathrm{Cm}(\mathrm{III})$ over $\mathrm{Am}(\mathrm{III})\left(\mathrm{SF}_{\mathrm{Cm} / \mathrm{Am}}\right.$, for hydrophilic ligands) observed with BTPhen ligands.

\begin{tabular}{|l|l|l|l|l|l|l|l|}
\hline Ligand & $\begin{array}{l}\text { Hydrophobic } \\
\text { or } \\
\text { hydrophilic? }\end{array}$ & $\mathbf{S F}_{\mathbf{A m} / \mathbf{C m}}$ & $\mathbf{S F}_{\mathbf{C m} / \mathbf{A m}}$ & Organic phase & $\begin{array}{l}\text { Aqueous } \\
\text { phase }\end{array}$ & $\begin{array}{l}\text { Contact } \\
\text { time }\end{array}$ & Reference \\
\hline $\mathbf{3}$ & hydrophobic & 3.3 & - & $\begin{array}{l}1 \mathrm{mM} \mathrm{L} \mathrm{in} \\
\text { octanol }\end{array}$ & $\begin{array}{l}6 \mathrm{M} \\
\mathrm{HNO}_{3}\end{array}$ & $2 \mathrm{~h}$ & this work \\
\hline $\mathbf{3}$ & hydrophobic & 4.0 & - & $\begin{array}{l}10 \mathrm{mM} \mathrm{L} \text { in } \\
\text { octanol:toluene } \\
(40: 60)\end{array}$ & $\begin{array}{l}4 \mathrm{M} \\
\mathrm{HNO}_{3}\end{array}$ & $1 \mathrm{~h}$ & $6 \mathrm{a}$ \\
\hline
\end{tabular}




\begin{tabular}{|c|c|c|c|c|c|c|c|}
\hline 3 & hydrophobic & 3.1 & - & $\begin{array}{l}10 \mathrm{mM} \mathrm{L} \text { in } \\
\text { octanol:toluene } \\
(40: 60)\end{array}$ & $\begin{array}{l}4 \mathrm{M} \\
\mathrm{HNO}_{3}\end{array}$ & $6 \mathrm{~h}$ & this work \\
\hline 3 & hydrophobic & 6.5 & - & $\begin{array}{l}10 \mathrm{mM} \mathrm{L} \text { in } \\
\text { octanol:toluene } \\
(40: 60)\end{array}$ & $\begin{array}{l}1 \mathrm{M} \\
\mathrm{HNO}_{3}\end{array}$ & $6 \mathrm{~h}$ & this work \\
\hline 3 & hydrophobic & 7.9 & - & $\begin{array}{l}5 \mathrm{mM} \mathrm{L} \text { in } \\
\text { octanol:toluene } \\
(40: 60)\end{array}$ & $\begin{array}{l}2.4 \mathrm{M} \\
\mathrm{HNO}_{3}\end{array}$ & $10 \mathrm{~h}$ & this work \\
\hline 3 & hydrophobic & 4.0 & - & $\begin{array}{l}1 \mathrm{mM} \mathrm{L} \text { in } \\
\text { octanol:toluene } \\
(40: 60)\end{array}$ & $\begin{array}{l}4 \mathrm{M} \\
\mathrm{HNO}_{3}\end{array}$ & $20 \min$ & this work \\
\hline $\begin{array}{l}\text { 5-Br } \\
\text { CyMe} 4-_{4} \\
\text { BTPhen }\end{array}$ & hydrophobic & 7.0 & - & $30 \mathrm{mM}$ in octanol & $\begin{array}{l}0.1 \mathrm{M} \\
\mathrm{HNO}_{3}\end{array}$ & $?$ & 17 \\
\hline $\begin{array}{l}\text { 5-( }\left(\mathrm{HOC}_{6} \mathrm{H}_{4}\right) \\
\text { CyMe} 4- \\
\text { BTPhen }\end{array}$ & hydrophobic & 5.0 & - & $30 \mathrm{mM}$ in octanol & $\begin{array}{l}1 \mathrm{M} \\
\mathrm{HNO}_{3}\end{array}$ & $?$ & 17 \\
\hline 3 & hydrophobic & 6.7 & - & $\begin{array}{l}5 \mathrm{mM} \mathrm{L} \text { in } \\
\text { cyclohexanone }\end{array}$ & $\begin{array}{l}0.5 \mathrm{M} \\
\mathrm{HNO}_{3}\end{array}$ & $7 \mathrm{~min}$ & this work \\
\hline 3 & hydrophobic & 4.2 & - & $\begin{array}{l}5 \mathrm{mM} \mathrm{L} \text { in } \\
\text { cyclohexanone }\end{array}$ & $\begin{array}{l}1 \mathrm{M} \\
\mathrm{HNO}_{3}\end{array}$ & $7 \mathrm{~min}$ & this work \\
\hline 3 & hydrophobic & 5.5 & - & $\begin{array}{l}5 \mathrm{mM} \mathrm{L} \text { in } \\
\text { cyclohexanone }\end{array}$ & $\begin{array}{l}0.5 \mathrm{M} \\
\mathrm{HNO}_{3}\end{array}$ & $7 \mathrm{~min}$ & this work \\
\hline 3 & hydrophobic & 4.8 & - & $\begin{array}{l}5 \mathrm{mM} \mathrm{L} \text { in } \\
\text { cyclohexanone }\end{array}$ & $\begin{array}{l}1 \mathrm{M} \\
\mathrm{HNO}_{3}\end{array}$ & $10 \min$ & this work \\
\hline 4 & hydrophobic & 3.1 & - & $\begin{array}{l}5 \mathrm{mM} \mathrm{L} \text { in } \\
\text { cyclohexanone }\end{array}$ & $\begin{array}{l}0.5 \mathrm{M} \\
\mathrm{HNO}_{3}\end{array}$ & $30 \mathrm{~min}$ & this work \\
\hline 5 & hydrophobic & 2.6 & - & $\begin{array}{l}5 \mathrm{mM} \mathrm{L} \text { in } \\
\text { cyclohexanone }\end{array}$ & $\begin{array}{l}0.5 \mathrm{M} \\
\mathrm{HNO}_{3}\end{array}$ & $30 \min$ & this work \\
\hline 9 & hydrophilic & - & 4.6 & $\begin{array}{l}0.2 \mathrm{M} \text { TODGA in } \\
\text { octanol:kerosene } \\
(5: 95)\end{array}$ & $\begin{array}{l}10 \mathrm{mM} \mathrm{L} \\
\text { in } 0.28 \mathrm{M} \\
\mathrm{HNO}_{3}\end{array}$ & $6 \mathrm{~h}$ & this work \\
\hline 9 & hydrophilic & - & 4.6 & $\begin{array}{l}0.2 \mathrm{M} \text { TODGA in } \\
\text { octanol:kerosene } \\
(5: 95)\end{array}$ & $\begin{array}{l}10 \mathrm{mM} \mathrm{L} \\
\text { in } 0.5 \mathrm{M} \\
\mathrm{HNO}_{3}\end{array}$ & $6 \mathrm{~h}$ & this work \\
\hline 10 & hydrophilic & - & 3.2 & $\begin{array}{l}0.2 \mathrm{M} \text { TODGA in } \\
\text { octanol:kerosene } \\
(5: 95)\end{array}$ & $\begin{array}{l}10 \mathrm{mM} \mathrm{L} \\
\text { in } 0.5 \mathrm{M} \\
\mathrm{HNO}_{3}\end{array}$ & $6 \mathrm{~h}$ & this work \\
\hline 9 & hydrophilic & - & 3.3 & $\begin{array}{l}0.2 \mathrm{M} \text { TODGA in } \\
\text { octanol:kerosene }\end{array}$ & $\begin{array}{l}10 \mathrm{mM} \mathrm{L} \\
\text { in } 0.77 \mathrm{M}\end{array}$ & $6 \mathrm{~h}$ & this work \\
\hline
\end{tabular}




\begin{tabular}{|c|c|c|c|c|c|c|c|}
\hline & & & & $(5: 95)$ & $\mathrm{HNO}_{3}$ & & \\
\hline 10 & hydrophilic & - & 3.4 & $\begin{array}{l}0.2 \text { M TODGA in } \\
\text { octanol:kerosene } \\
(5: 95)\end{array}$ & $\begin{array}{l}10 \mathrm{mM} \mathrm{L} \\
\text { in } 0.77 \mathrm{M} \\
\mathrm{HNO}_{3}\end{array}$ & $6 \mathrm{~h}$ & this work \\
\hline 9 & hydrophilic & - & 3.8 & $\begin{array}{l}0.2 \mathrm{M} \text { TODGA in } \\
\text { octanol:kerosene } \\
(5: 95)\end{array}$ & $\begin{array}{l}10 \mathrm{mM} \mathrm{L} \\
\text { in } 1.04 \mathrm{M} \\
\mathrm{HNO}_{3}\end{array}$ & $6 \mathrm{~h}$ & this work \\
\hline 9 & hydrophilic & - & 3.3 & $\begin{array}{l}0.2 \mathrm{M} \text { TODGA in } \\
\text { octanol:TPH } \\
(5: 95)\end{array}$ & $\begin{array}{l}10 \mathrm{mM} \mathrm{L} \\
\text { in } 0.6 \mathrm{M} \\
\mathrm{HNO}_{3}\end{array}$ & $1 \mathrm{~min}$ & $8 d$ \\
\hline 9 & hydrophilic & - & 3.6 & $\begin{array}{l}0.2 \mathrm{M} \text { TODGA in } \\
\text { octanol:TPH } \\
(5: 95)\end{array}$ & $\begin{array}{l}10 \mathrm{mM} \mathrm{L} \\
\text { in } 0.65 \mathrm{M} \\
\mathrm{HNO}_{3}\end{array}$ & $5 \mathrm{~min}$ & $8 \mathrm{f}$ \\
\hline 7 & hydrophilic & - & 2.4 & $\begin{array}{l}0.2 \mathrm{M} \text { TODGA in } \\
\text { octanol:kerosene } \\
(5: 95)\end{array}$ & $\begin{array}{l}10 \mathrm{mM} \mathrm{L} \\
\text { in } 0.5 \mathrm{M} \\
\mathrm{HNO}_{3}\end{array}$ & $6 \mathrm{~h}$ & this work \\
\hline 7 & hydrophilic & - & $\sim 2.5$ & $\begin{array}{l}0.2 \text { M TODGA in } \\
\text { octanol:Exxsol } \\
\text { D80 (5:95) }\end{array}$ & $\begin{array}{l}10 \mathrm{mM} \mathrm{L} \\
\text { in } 0.5 \mathrm{M} \\
\mathrm{HNO}_{3}\end{array}$ & $30 \mathrm{~min}$ & $8 \mathrm{e}$ \\
\hline & & & & & & & \\
\hline & & & & & & & \\
\hline & & & & & & & \\
\hline & & & & & & & \\
\hline & & & & & & & \\
\hline & & & & & & & \\
\hline & & & & & & & \\
\hline & & & & & & & \\
\hline & & & & & & & \\
\hline
\end{tabular}

\section{Conclusions}

We have studied the complexation and extraction of the similar adjacent trivalent minor actinides Am(III) and Cm(III) by hydrophobic and hydrophilic 2,9-bis(1,2,4-triazin-3-yl)-1,10phenanthroline (BTPhen) ligands. A kinetic effect was observed in the extraction of Am(III) and 
$\mathrm{Cm}(\mathrm{III})$ by hydrophobic ligand $\mathrm{CyMe}_{4}-\mathrm{BTPhen} 3$ into three different diluents (octanol, octanol:toluene 40:60, cyclohexanone), leading to a more rapid extraction of Am(III) than $\mathrm{Cm}(\mathrm{III})$. Separation factor for $\mathrm{Am}(\mathrm{III})$ over $\mathrm{Cm}(\mathrm{III})\left(\mathrm{SF}_{\mathrm{Am} / \mathrm{Cm}}\right)$ as high as 7.9 are observed under these non-equilibrium (kinetic) extraction conditions. This kinetic effect can be tuned through careful choice of the extraction variables (organic diluent, contact time, shaking speed, ligand concentration) and could thus potentially be exploited to carry out the challenging but necessary separation of $\mathrm{Am}(\mathrm{III})$ from $\mathrm{Cm}(\mathrm{III})$ in a future closed nuclear fuel cycle. In contrast, no such kinetic effect is observed with BTPhen ligands $\mathbf{4}$ and $\mathbf{5}$ containing linear alkyl groups, and these ligands do not separate $\mathrm{Am}(\mathrm{III})$ from $\mathrm{Cm}(\mathrm{III})$ as effectively as $\mathbf{3}$.

We attribute this kinetic separation to the slightly higher kinetic lability of the Am(III) aqua complex towards ligand substitution compared to the $\mathrm{Cm}(\mathrm{III})$ aqua complex, in analogy with the known trend in kinetic labilities of the corresponding trivalent lanthanide aqua complexes. Finally we have shown that, under equilibrium conditions, hydrophilic tetrasulfonated BTPhen ligands 9 and 10 can complex selectively Am(III) over Cm(III) in nitric acid and suppress its extraction by TODGA, leading to effective separations of $\mathrm{Am}$ (III) from $\mathrm{Cm}$ (III) $\left(\mathrm{SF}_{\mathrm{Cm} / \mathrm{Am}}\right.$ up to 4.6 observed). Taken together with the separation factors reported previously in the literature (summarized collectively in Table 1), these results underline both hydrophobic and hydrophilic pre-organized 2,9-bis(1,2,4-triazin-3-yl)-1,10-phenanthroline (BTPhen) ligands as promising candidates for the difficult separation of Am(III) from Cm(III) in used nuclear fuel reprocessing, either under kinetic or thermodynamic (ie: equilibrium) extraction conditions.

\section{Experimental Section}

Materials and Methods. The hydrophobic ligands $\mathrm{CyMe}_{4}$-BTPhen $3{ }^{6 \mathrm{aa}} \mathrm{C} 4-\mathrm{BTPhen} \mathbf{4}^{19}$ and C5-BTPhen $\mathbf{5}^{19,20}$ were synthesized at the University of Reading as reported previously. The 
hydrophilic sulfonated ligands $\mathbf{7 - 1 2}$ were also synthesized at the University of Reading as described previously. ${ }^{8 \mathrm{c}}$ The stock solution of ${ }^{241} \mathrm{Am}$ in $\mathrm{HNO}_{3}$ was prepared by dissolving americium oxide in $5 \mathrm{M} \mathrm{HNO}_{3}$ and subsequent dilution with water. The stock solution of ${ }^{152} \mathrm{Eu}$ was prepared by appropriate dilution of a commercial preparation (REu-2) supplied by Polatom (Poland). The stock solution of ${ }^{244} \mathrm{Cm}$ was prepared by dissolving moist curium nitrate ( $37 \mathrm{MBq}$, reference date 16th February 2007, TENEX Russia) in $2 \mathrm{~mL}$ of $0.01 \mathrm{M} \mathrm{HNO}_{3}$ by appropriate dilution with water. The working solutions of all radionuclides were prepared from the respective radionuclide stock solutions by appropriate dilution. Solvent extraction measurements were performed at the Czech Technical University in Prague (Czech Republic).

Solvent Extraction Measurements with Hydrophobic Ligands. The aqueous solutions were prepared by spiking nitric acid solutions $\left(0.01-4 \mathrm{~mol} \mathrm{dm}^{-3}\right)$ with working solutions of ${ }^{241} \mathrm{Am}$, ${ }^{244} \mathrm{Cm}$ and ${ }^{152} \mathrm{Eu}$ tracers in diluted nitric acid. Solutions of the hydrophobic ligands $\mathbf{3}-\mathbf{5}$ were prepared by dissolving in the appropriate diluent. Prior to labelling, the aqueous phases were preequilibrated with the neat diluents by shaking them for $4 \mathrm{~h}$ at $400 \mathrm{~min}^{-1}$ and volume ratio of $4: 1$. The organic phases were pre-equilibrated with the respective non-labelled aqueous phases by shaking them for $4 \mathrm{~h}$ at $400 \mathrm{~min}^{-1}$ and volume ratio of 1:1. In each case, $1.22 \mathrm{~mL}$ of labelled aqueous phases were prepared from which one $200 \mu \mathrm{L}$ and two $10 \mu \mathrm{L}$ standards were taken (to allow for mass balance calculations) prior to contacting the aqueous phases with the organic phases. Each organic phase $(1 \mathrm{~mL})$ was shaken separately with each of the aqueous phases for a given time at a thermostatted temperature using an GFL 3005 Orbital Shaker $\left(250 \mathrm{~min}^{-1}\right)$, or a Heidolph Multi Reax Shaker $\left(1800 \mathrm{~min}^{-1}\right)$. After phase separation by centrifugation, two parallel $200 \mu \mathrm{L}$ and two $10 \mu \mathrm{L}$ aliquots of each phase were withdrawn for gamma or alpha measurements, respectively. 
For alpha measurements, the aliquots were deposited on stainless steel planchets, evaporated to dryness under an infra-red lamp, and heated in a burner flame until the sample glowed with a dull red colour. ${ }^{41}$ The same procedure was used to investigate the kinetics of ${ }^{241} \mathrm{Am}$ and ${ }^{244} \mathrm{Cm}$ extraction. Alpha activity measurements of ${ }^{241} \mathrm{Am}$ and ${ }^{244} \mathrm{Cm}$ were performed with ORTEC ${ }^{\circledR}$ OCTETE Plus Integrated Alpha-Spectroscopy System equipped with ion-implanted-silicon ULTRA Alpha Detector Model BU-020-450-AS. The double peaks at $5443+5486 \mathrm{keV}$ and $5763+5805 \mathrm{keV}$ in the alpha spectra were evaluated for ${ }^{241} \mathrm{Am}$ and ${ }^{244} \mathrm{Cm}$, respectively, by AlphaVision-32 Alpha Analysis Software (ORTEC, Advanced Measurement Technology, Inc., USA).

For gamma measurements, the aliquots were pipetted into glass ampules, their walls were washed with $1 \mathrm{~mL}$ of distilled water or the diluent used and the ampoules were covered with a piece of parafilm. Gamma activity measurements of ${ }^{241} \mathrm{Am}$ and ${ }^{152} \mathrm{Eu}$ were performed with a $\gamma$ ray spectrometer EG\&G Ortec (USA) with a PGT (USA) HPGe detector. The $\gamma$-lines at 59.5 $\mathrm{keV}$, and $121.8 \mathrm{keV}$ were examined for ${ }^{241} \mathrm{Am}$, and ${ }^{152} \mathrm{Eu}$, respectively.

The errors given in the figures are $2 \sigma$ propagated errors based on counting statistics, sample preparation, and sampling errors. Caution! ${ }^{241} \mathrm{Am},{ }^{244} \mathrm{Cm}$ and ${ }^{152} \mathrm{Eu}$ are highly radioactive isotopes. All radiotracer experiments were carried out in radiochemical laboratories equipped and granted with permission for handling these isotopes.

Solvent Extraction Measurements with Hydrophilic Ligands. The aqueous solutions were prepared by spiking $1.19 \mathrm{~mL}$ of nitric acid solutions $\left(0.28-1.04 \mathrm{~mol} \mathrm{~L}^{-1}\right)$ with or without the hydrophilic sulfonated ligand 7-12 $\left(10 \mathrm{mmol} \mathrm{L}^{-1}\right)$ with $10 \mu \mathrm{L}$ of working solutions of ${ }^{241} \mathrm{Am}$, ${ }^{244} \mathrm{Cm}$, and ${ }^{152} \mathrm{Eu}$ radiotracers. The organic phase solutions consisted of $0.2 \mathrm{~mol} \mathrm{~L}^{-1} \mathrm{TODGA}$ dissolved in $5 \%$ vol. 1-octanol in kerosene. In each case before contacting with the organic 
phase, an aliquot of $200 \mu \mathrm{L}$ was taken from the labeled aqueous phases to measure the gamma activity of europium, and two $10 \mu \mathrm{L}$ aliquots to measure the alpha activity of americium and curium, to allow for activity balance calculations. Each organic phase $(1 \mathrm{~mL})$ was shaken with each of the aqueous phases $(1 \mathrm{~mL})$ for a given time at a thermostatted temperature, using a horizontal GFL 3005 Orbital Shaker $\left(250 \mathrm{~min}^{-1}\right)$. After phase separation by centrifugation (1 minute, $6000 \mathrm{rot} / \mathrm{min}$ ), two parallel $200 \mu \mathrm{L}$ aliquots of each phase were withdrawn into glass ampules for the gamma measurements. The walls of the glass ampules were washed with $1 \mathrm{~mL}$ of distilled water or 5 vol. \% 1-octanol in kerosene and ampules were covered with a piece of parafilm. For the alpha spectrometry, two parallel $10 \mu \mathrm{L}$ aliquots of each phase were withdrawn and samples prepared as described above. Sample preparation for the alpha measurements, and the measurement of both the alpha and gamma activities, were performed as described above.

ASSOCIATED CONTENT. Tables and graphs of solvent extraction data for hydrophobic ligands 3-5 and hydrophilic ligands 7-12. This material is available free of charge via the Internet at http://pubs.acs.org.

AUTHOR INFORMATION

\section{Corresponding Author}

* Frank Lewis. Email: frank.lewis@northumbria.ac.uk.

\section{ACKNOWLEDGMENT}

We thank the Nuclear Fission Safety Program of the European Union for support under the ACSEPT (FP7-CP-2007-211267) and SACSESS (FP7-CP-2012-323282) contracts, and the Grant Agency of the Czech Technical University in Prague (grant No. SGS15/216/OHK4/3T/14). We also gratefully acknowledge the use of the Chemical Analysis Facility at the University of Reading. 


\section{REFERENCES}

1. Nash, K. L.; Madic, C.; Mathur, J.; Lacquement, J. The Chemistry of the Actinide and Transactinide Elements, Vol. 4; Morss, L. R.; Edelstein, N. M.; Fuger, J., Eds.; Springer: Dordrecht, 2011, pp 2622-2798.

2. (a) Nash, K. L.; Solvent Extr. Ion Exch. 1993, 11, 729-768. (b) Mathur, J. N.; Murali, M. S.; Nash, K. L. Solvent Extr. Ion Exch. 2001, 19, 357-390. (c) Lumetta, G. J.; Gelis, A. V.; Vandegrift, G. F. Solvent Extr. Ion Exch. 2010, 28, 287-312. (d) Hill, C. Ion Exchange and Solvent Extraction: A Series of Advances, Vol. 19; Moyer, B. A., Ed.; CRC Press: Boca Raton, 2010, pp 119-193. (e) Modolo, G.; Wilden, A.; Geist, A.; Magnusson, D.; Malmbeck, R. Radiochim. Acta 2012, 100, 715-725.

3. Salvatores, M. Palmiotti, G. Prog. Part. Nucl. Phys. 2011, 66, 144-166.

4. (a) Dam, H. H.; Reinhoudt, D. N.; Verboom, W. Chem. Soc. Rev. 2007, 36, 367-377. (b) Ekberg, C.; Fermvik, A.; Retegan, T.; Skarnemark, G.; Foreman, M. R. S.; Hudson, M. J.; Englund, S.; Nilsson, M. Radiochim. Acta 2008, 96, 225-233. (c) Kolarik, Z. Chem. Rev. 2008, 108, 4208-4252. (d) Lewis, F. W.; Hudson, M. J.; Harwood, L. M. Synlett 2011, 2609-2632. (e) Hudson, M. J.; Harwood, L. M.; Laventine, D. M.; Lewis, F. W. Inorg. Chem. 2013, 52, 3414-3428. (f) Hudson, M. J.; Lewis, F. W.; Harwood, L. M. Strategies and Tactics in Organic Synthesis, Vol. 9; Harmata, M., Ed.; Elsevier: Amsterdam, 2013, pp 177-202. (g) Panak, P. J.; Geist, A. Chem. Rev. 2013, 113, 11991236. (h) Alyapyshev, M. Y.; Babain, V. A.; Ustynyuk, Y. A. Russ. Chem. Rev. 2016, 85, 943-961. 
5. (a) Geist, A.; Hill, C.; Modolo, G.; Foreman, M. R. St. J.; Weigl, M.; Gompper, K.; Hudson, M. J.; Madic, C. Solvent Extr. Ion Exch. 2006, 24, 463-483. (b) Magnusson, D.; Christiansen, B.; Foreman, M. R. S.; Geist, A.; Glatz, J.-P.; Malmbeck, R.; Modolo, G.; Serrano-Purroy, D.; Sorel, C. Solvent Extr. Ion Exch. 2009, 27, 97-106. (c) Wilden, A.; Schreinemachers, C.; Sypula, M.; Modolo, G. Solvent Extr. Ion Exch. 2011, 29, 190-212.

6. (a) Lewis, F. W.; Harwood, L. M.; Hudson, M. J.; Drew, M. G. B.; Desreux, J. F.; Vidick, G.; Bouslimani, N.; Modolo, G.; Wilden, A.; Sypula, M.; Vu, T.-H.; Simonin, J. P. J. Am. Chem. Soc. 2011, 133, 13093-13102. (b) Lewis, F. W.; Harwood, L. M.; Hudson, M. J.; Drew, M. G. B.; Wilden, A.; Sypula, M.; Modolo, G.; Vu, T.-H.; Simonin, J.-P.; Vidick, G.; Bouslimani, N.; Desreux, J. F. Proc. Chem. 2012, 7, 231-238. (c) Lewis, F. W.; Harwood, L. M.; Hudson, M. J.; Drew, M. G. B.; Hubscher-Bruder, V.; Videva, V.; Arnaud-Neu, F.; Stamberg, K.; Vyas, S. Inorg. Chem. 2013, 52, 4993-5005. (d) Afsar, A.; Harwood, L. M.; Hudson, M. J.; Distler, P.; John, J. Chem. Commun. 2014, 50, 15082-15085. (e) Edwards, A. C.; Wagner, C.; Geist, A.; Burton, N. A.; Sharrad, C. A.; Adams, R. W.; Pritchard, R. G.; Panak, P. J.; Whitehead, R. C.; Harwood, L. M. Dalton Trans. 2016, 45, 18102-18112.

7. (a) Weaver, B.; Kappelmann, F. A. TALSPEAK: A New Method of Separating Americium and Curium from the Lanthanides by Extraction from an Aqueous Solution of an Aminopolyacetic Acid Complex with a Monoacidic Organophosphate or Phosphonate, ORNL-3559, Oak Ridge National Laboratory, USA, 1964. (b) Starý, J. Talanta 1966, 13, 421-437. (c) Weaver, B.; Kappelmann, F. A. J. Inorg. Nucl. Chem. 1968, 30, 263-272. (d) Persson, G.; Svantesson, I.; Wingefors, S.; Liljenzin, J. O. Solvent Extr. Ion Exch. 1984, 2, 89-113. 
8. (a) Geist, A.; Müllich, U.; Magnusson, D.; Kaden, P.; Modolo, G.; Wilden, A.; Zevaco, T. Solvent Extr. Ion Exch. 2012, 30, 433-444. (b) Ruff, C. M.; Müllich, U.; Geist, A.; Panak, P. J. Dalton Trans. 2012, 41, 14594-14602. (c) Lewis, F. W.; Harwood, L. M.; Hudson, M. J.; Geist, A.; Kozhevnikov, V. N.; Distler, P.; John, J. Chem. Sci. 2015, 6, 4812-4821. (d) Kaufholz, P.; Sadowski, F.; Wilden, A.; Modolo, G.; Lewis, F. W.; Smith, A. W.; Harwood, L. M. Nukleonika 2015, 60, 815-820. (e) Wagner, C.; Müllich, U.; Geist, A.; Panak, P. J. Solvent Extr. Ion Exch. 2016, 34, 103-113. (f) Kaufholz, P.; Modolo, G.; Wilden, A.; Sadowski, F.; Bosbach, D.; Wagner, C.; Geist, A.; Panak, P. J.; Lewis, F. W.; Harwood, L. M. Solvent Extr. Ion Exch. 2016, 34, 126-140.

9. (a) Carrott, M.; Geist, A.; Hères, X.; Lange, S.; Malmbeck, R.; Miguirditchian, M.; Modolo, G.; Wilden, A.; Taylor, R. Hydrometallurgy 2015, 152, 139-148. (b) Wilden, A.; Modolo, G.; Kaufholz, P.; Sadowski, F.; Lange, S.; Sypula, M.; Magnusson, D.; Müllich, U.; Geist, A.; Bosbach, D. Solvent Extr. Ion Exch. 2015, 33, 91-108.

10. (a) Pillon, S.; Somers, J.; Grandjean, S.; Lacquement, J. J. Nucl. Mater. 2003, 320, 3643. (b) Lebreton, F.; Prieur, D.; Horlait, D.; Delahaye, T.; Jankowiak, A.; Léorier, C.; Jorion, F.; Gavilan, E.; Desmoulière, F. J. Nucl. Mater. 2013, 438, 99-107.

11. David, F. J. Less-Common Met. 1986, 121, 27-42.

12. D’Angelo, P.; Martelli, F.; Spezia, R.; Filipponi, A.; Denecke, M. A. Inorg. Chem. 2013, $52,10318-10324$

13. (a) Modolo, G.; Nabet, S. Solvent Extr. Ion Exch. 2005, 23, 359-373. (b) Modolo, G.; Kluxen, P.; Geist, A. Radiochim. Acta 2010, 98, 193-201. 
14. (a) Rostaing, C.; Poinssot, C.; Warin, D.; Baron, P.; Lorrain, B. Proc. Chem. 2012, 7, 367-373. (b) Chapron, S.; Marie, C.; Arrachart, G.; Miguirditchian, M.; Pellet-Rostaing, S. Solvent Extr. Ion Exch. 2015, 33, 236-248.

15. For a review, see: Runde, W. H.; Mincher, B. J. Chem. Rev. 2011, 111, 5723-5741.

16. Burns, J. D.; Shehee, T. C.; Clearfield, A.; Hobbs, D. T. Anal. Chem. 2012, 84, 69306932.

17. (a) Martin, L. R.; Mincher, B. J.; Schmitt, N. C. J. Radioanal. Nucl. Chem. 2009, 28, 523-526. (b) Mincher, B. J.; Martin, L. R.; Schmitt, N. C. Solvent Extr. Ion Exch. 2012, 30, 445-456. (c) Mincher, B. J.; Schmitt, N. C.; Tillotson, R. D.; Elias, G.; White, B. M.; Law, J. D. Solvent Extr. Ion Exch. 2014, 32, 153-166. (d) Law, J.; Mincher, B.; Garn, T.; Greenhalgh, M.; Schmitt, N.; Rutledge, V. Development and Testing of an Americium/Lanthanide Separation Flowsheet Using Sodium Bismuthate, Proceedings of ICAPP 2014, Charlotte, North Carolina, USA, 6-9 April 2014, Paper 14040. (e) Mincher, B. J. Am(VI) Partitioning Studies: FY14 Final Report, Report Number INL/EXT-1433297, Idaho National Laboratory, Idaho Falls, Idaho 83415, USA, 2014 (https://www.osti.gov/scitech/biblio/1173084/). (f) Richards, J. M.; Sudowe, R. Anal. Chem. 2016, $88,4605-4608$.

18. (a) Jensen, M. P.; Chiarizia, R.; Shkrob, I. A.; Ulicki, J. S.; Spindler, B. D.; Murphy, D. J.; Hossain, M.; Roca-Sabio, A.; Platas-Iglesias, C.; de Blas, A.; Rodríguez-Blas, T. Inorg. Chem. 2014, 53, 6003-6012. (b) Jensen, M. P.; Chiarizia, R.; Ulicki, J. S.; Spindler, B. D.; Murphy, D. J.; Mahmun Hossain, M.; Roca-Sabio, A.; de Blas, A.; Rodríguez-Blas, T. Solvent Extr. Ion Exch. 2015, 33, 329-345. 
19. Afsar, A.; Harwood, L. M.; Hudson, M. J.; Westwood, J.; Geist, A. Chem. Commun. 2015, 51, 5860-5863.

20. (a) Aneheim, E.; Ekberg, C.; Fermvik, A.; Foreman, M. R. St. J.; Retegan, T.; Skarnemark, G. Solvent Extr. Ion Exch. 2010, 28, 437-458. (b) Aneheim, E.; Ekberg, C.; Fermvik, A.; Foreman, M. R. St. J.; Grüner, B.; Hájková, Z.; Kvičalová, M. Solvent Extr. Ion Exch. 2011, 29, 157-175. (c) Retegan, T.; Drew, M.; Ekberg, C.; Löfström-Engdahl, E.; Hudson, M. J.; Fermvik, A.; Foreman, M. R. S.; Modolo, G.; Geist, A. Solvent Extr. Ion Exch. 2014, 32, 720-736.

21. Laventine, D. M.; Afsar, A.; Hudson, M. J.; Harwood, L. M. Heterocycles 2012, 86, $1419-1429$.

22. Afsar, A.; Laventine, D. M.; Harwood, L. M.; Hudson, M. J.; Geist, A. Chem. Commun. 2013, 49, 8534-8536.

23. (a) Cabicar, J.; Štamberg, K. Czech Patent No. 214904, 1978. (b) Cabicar, J.; Štamberg, K. React. Polym. 1983, 1, 309-314. (c) Cabicar, J.; Štamberg, K. Isotopenpraxis 1984, $20,173-179$.

24. (a) Štamberg, K.; Vopálka, D.; Štěpánek, J. The Basic Principles of Separation Processes and their Mathematical-Physical Modeling. The Models of Ternary Isotope Systems, Report No. KJCH 42Z, Czech Technical University in Prague, Prague, Czech Republic, 1990. (b) Vařeka, J.; Štěpánek, J.; Štamberg, K. Technology and Apparatus Research of Uranium Isotope Separation in Pilot-Plant Scale and an Estimate of the Technological- 
Economic Parameters of the Process, Research Report VZUP, Report No. ÚJP-692, Institute of Nuclear Fuels, Prague-Zbraslav, Czech Republic, 1990.

25. Plicka, J.; Štamberg, K.; Cabicar, J.; Spěváčková, V. React. Polym. 1988, 7, 141-150.

26. (a) Lakshmanan, V. I.; Lawson, G. J.; Nyholm, P. S. The Extraction of Copper(II) and Iron(III) with Kelex 100 from Aqueous Media Containing Chloride Ions, ISEC Proceedings, 1974, 2, 1169-1183. (b) Flett, D. S.; Hartlage, J. A.; Spink, D. R.; Okuhara, D. N. J. Inorg. Nucl. Chem. 1975, 37, 1967-1971. (c) Ohashi, K.; Nakata, S.; Katsume, M.; Nakamura, K.; Yamamoto, K. Anal. Sci. 1985, 1, 467-471.

27. For reviews, see: (a) Kaltsoyannis, N. Inorg. Chem. 2013, 52, 3407-3413. (b) Neidig, M. L.; Clark, D. L.; Martin, R. L. Coord. Chem. Rev. 2013, 257, 394-406.

28. (a) Adam, C.; Kaden, P.; Beele, B. B.; Müllich, U.; Trumm, S.; Geist, A.; Panak, P. J.; Denecke, M. A. Dalton Trans. 2013, 42, 14068-14074. (b) Adam, C.; Beele, B. B.; Geist, A.; Müllich, U.; Kaden, P.; Panak, P. J. Chem. Sci. 2015, 6, 1548-1561. (c) Wagner, C.; Ruff, C.; Müllich, U.; Geist, A.; Panak, P. J. New J. Chem. 2016, 40, 9232 9237.

29. (a) Denecke, M. A.; Rossberg, A.; Panak, P. J.; Weigl, M.; Schimmelpfennig, B.; Geist, A. Inorg. Chem. 2005, 44, 8418-8425. (b) Denecke, M. A.; Panak, P. J.; Burdet, F.; Weigl, M.; Geist, A.; Klenze, R.; Mazzanti, M.; Gompper, K. C. R. Chim. 2007, 10, 872882. (c) Banik, N. L.; Denecke, M. A.; Geist, A.; Modolo, G.; Panak, P. J.; Rothe, J. Inorg. Chem. Commun. 2013, 29, 172-174. 
30. (a) Trumm, S.; Lieser, G.; Foreman, M. R. S. J.; Panak, P. J.; Geist, A.; Fanghänel, T. Dalton Trans. 2010, 39, 923-929. (b) Wagner, C.; Müllich, U.; Geist, A.; Panak, P. J. Dalton Trans. 2015, 44, 17143-17151.

31. Bremer, A.; Whittaker, D. M.; Sharrad, C. A.; Geist, A.; Panak, P. J. Dalton Trans. 2014, 43, 2684-2694.

32. Ekberg, C.; Löfström-Engdahl, E.; Aneheim, E.; Foreman, M. R. St. J.; Geist, A.; Lundberg, D.; Denecke, M. A.; Persson, I. Dalton Trans. 2015, 44, 18395-18402.

33. (a) Steppert, M.; Císařová, I.; Fanghänel, T.; Geist, A.; Lindqvist-Reis, P.; Panak, P.; Štěpnička, P.; Trumm, S.; Walther, C. Inorg. Chem. 2012, 51, 591-600. (b) Whittaker, D. M.; Griffiths, T. L.; Helliwell, M.; Swinburne, A. N.; Natrajan, L. S.; Lewis, F. W.; Harwood, L. M.; Parry, S. A.; Sharrad, C. A. Inorg. Chem. 2013, 52, 3429-3444.

34. (a) Cossy, C.; Helm, L.; Merbach, A. E. Inorg. Chem. 1988, 27, 1973-1979. (b) Kobayashi, S.; Nagayama, S.; Busujima, T. J. Am. Chem. Soc. 1998, 120, 8287-8288. (c) Helm, L.; Nicolle, G. M.; Merbach, A. E. Adv. Inorg. Chem. 2005, 57, 327-379.

35. (a) Farkas, I.; Grenthe, I.; Bányai, I. J. Phys. Chem. A 2000, 104, 1201-1206. (b) Szabó, Z.; Toraishi, T.; Vallet, V.; Grenthe, I. Coord. Chem. Rev. 2006, 250, 784-815.

36. Choppin, G. R.; Jensen, M. P. The Chemistry of the Actinide and Transactinide Elements, Vol. 4; Morss, L. R.; Edelstein, N. M.; Fuger, J., Eds.; Springer: Dordrecht, 2011, pp $2524-2621$.

37. Gordon, S.; Sullivan, J. C.; Ross, A. B. J. Phys. Chem. Ref. Data 1986, 15, 1357-1367. 
38. (a) Colette, S.; Amekraz, B.; Madic, C.; Berthon, L.; Cote, G.; Moulin, C. Inorg. Chem. 2002, 41, 7031-7041. (b) Colette, S.; Amekraz, B.; Madic, C.; Berthon, L.; Cote, G.; Moulin, C. Inorg. Chem. 2003, 42, 2215-2226. (c) Colette, S.; Amekraz, B.; Madic, C.; Berthon, L.; Cote, G.; Moulin, C. Inorg. Chem. 2004, 43, 6745-6751.

39. (a) Sasaki, Y.; Sugo, Y.; Suzuki, S.; Tachimori, S. Solvent Extr. Ion Exch. 2001, 19, 91103. (b) Modolo, G.; Asp, H.; Schreinemachers, C.; Vijgen, H. Solvent Extr. Ion Exch. 2007, 25, 703-721. (c) Modolo, G.; Asp, H.; Vijgen, H.; Malmbeck, R.; Magnusson, D.; Sorel, C. Solvent Extr. Ion Exch. 2008, 26, 62-76.

40. For other recent examples, see: (a) Lewis, F. W.; Harwood, L. M.; Hudson, M. J.; Núñez, A.; Galán, H.; Espartero, A. G. Synlett 2016, 27, 1-5. (b) Macerata, E.; Mossini, E.; Scaravaggi, S.; Mariani, M.; Mele, A.; Panzeri, W.; Boubals, N.; Berthon, L.; Charbonnel, M.-C.; Sansone, F.; Arduini, A.; Casnati, A. J. Am. Chem. Soc. 2016, 138, $7232-7235$.

41. Št’astná, K.; Fiala, V.; John, J. J. Radioanal. Nucl. Chem. 2010, 268, 735-739.

\footnotetext{
${ }^{1}$ Reference 1 in rejected Am/Cm separation paper (ACS Version)

${ }^{2}$ Reference 4 in our 2015 Sulfonates paper

${ }^{3}$ Reference 2 in rejected Am/Cm separation paper (ACS Version)

${ }^{4}$ References 3-6 in rejected Am/Cm separation paper (ACS Version), 2016 Russ. Chem. Rev. review

${ }^{5}$ References 7-9 in rejected Am/Cm separation paper (ACS Version)

${ }^{6}$ References 10-12 in rejected Am/Cm separation paper (ACS Version)

${ }^{7}$ Reference 19 in our 2015 Sulfonates paper

${ }^{8}$ References $24 \mathrm{a}$ and $24 \mathrm{~b}$ in our 2015 Sulfonates paper, our 2015 Sulfonates paper

${ }^{9}$ References $24 \mathrm{c}$ and $24 \mathrm{~d}$ in our 2015 Sulfonates paper
} 
${ }^{10}$ References 13 and 14 in rejected Am/Cm separation paper (ACS Version)

${ }^{11}$ Reference 15 in rejected $\mathrm{Am} / \mathrm{Cm}$ separation paper (ACS Version)

${ }^{12}$ Reference 16 in rejected $\mathrm{Am} / \mathrm{Cm}$ separation paper (ACS Version)

${ }^{13}$ References 17 and 18 in rejected Am/Cm separation paper (ACS Version)

${ }^{14}$ References 19 and 20 in rejected Am/Cm separation paper (ACS Version)

${ }^{15}$ Chem Rev 2011, 111, 5723-5741

${ }^{16}$ Reference 21 in rejected Am/Cm separation paper (ACS Version)

${ }^{17}$ See Bruce Mincher papers (SXIX, 2012, 30, 445-456, SXIX, 2014, 32, 153-166)

${ }^{18}$ References 22 and 23 in rejected Am/Cm separation paper (ACS Version)

${ }^{19}$ Reference 24 in rejected Am/Cm separation paper (ACS Version)

${ }^{20} \operatorname{Ref} 25-27$ in rejected Am/Cm separation paper (ACS Version)

${ }^{21}$ Reference 28 in rejected Am/Cm separation paper (ACS Version)

${ }^{22}$ Reference 29 in rejected Am/Cm separation paper (ACS Version)

${ }^{23}$ References 30-32 in rejected Am/Cm separation paper (ACS Version)

${ }^{24}$ References 33 and 34 in rejected $\mathrm{Am} / \mathrm{Cm}$ separation paper (ACS Version)

${ }^{25}$ Reference 35 in rejected Am/Cm separation paper (ACS Version)

26 44, 45 (References on Kelex 100)

${ }^{27}$ Reference 7 in our 2015 Sulfonates paper

${ }^{28} 33,31,32$

${ }^{29} 36,35,37$

${ }^{30} 28,34$

${ }^{31} 30$

3229

${ }^{33}$ Our 2013 Inorg. Chem. Manchester paper

${ }^{34} 22,23,27$

${ }^{35} 24,26$

${ }^{36}$ The Chemistry of the Actinide and Trans-actinide Elements, $4^{\text {th }}$ Ed, Springer, 2011.

${ }^{37} 25$

${ }^{38} 18,19,20$ 
${ }^{39}$ Ref 30 in our 2015 Sulfonates paper

${ }^{40}$ For a recent example, see: 21

${ }^{41}$ Reference 36 in rejected $\mathrm{Am} / \mathrm{Cm}$ separation paper (ACS Version) 